\title{
Cretaceous tectonostratigraphy of the Faroe-Shetland region
}

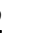

\author{
Martyn S Stoker \\ British Geological Survey, The Lyell Centre, Research Avenue South, Edinburgh, EH14 4AP, UK \\ *Corresponding author (e-mail: mss@bgs.ac.uk)
}

\section{Synopsis}

This study presents an appraisal of the Cretaceous tectonostratigraphical development of the

Faroe-Shetland region. It combines details of the rock record with seismic stratigraphical

information, and the resulting stratigraphic framework provides constraints on the timing and

nature of sedimentary basin development in the Faroe-Shetland region, with implications for the Late Mesozoic development of the NE Atlantic Rift Zone. The division of the Cretaceous succession into two megasequences (K1 \& K2) provides a first-order analysis of basin development. The components of the K1 megasequence represent the rift initiation and early syn-rift phases that span the late Berriasian-Turonian, whereas the K2 megasequence represents the rift climax incorporating basin enlargement and increased subsidence during the Coniacian-Maastrichtian. A higher resolution (second- to third-order) analysis of the component depositional packages highlights a sedimentary succession that is punctuated by episodes of uplift, erosion and contractional deformation. This pattern of coeval extension and compression is consistent with intra-plate strike-slip tectonic activity linked to the development of the NE Atlantic Rift Zone, and modulated by plate boundary processes, including Atlantic spreading and Alpine orogenic activity. There is no evidence for a substantive through-going marine connection in the Faroe-Shetland region until the Late Cretaceous.

\section{Introduction}


The Faroe-Shetland region is an area of complex geological structure located on the outer continental margin between northern Scotland (Orkney and Shetland islands) and the Faroe Islands (Fig. 1). This structural framework comprises a series of basins and highs that record a prolonged history of extension and rifting that took place episodically during the Late Palaeozoic, Mesozoic and Early Cenozoic. Devono-Carboniferous basins are a relic of postCaledonian orogenic collapse, whereas Permo-Triassic, (mainly Late) Jurassic and Cretaceous basin development is related to the fragmentation of Pangaea, ultimately leading to continental breakup to the north and west of the Faroe Islands in the earliest Eocene (Doré et al. 1999; Roberts et al. 1999; Passey \& Hitchen 2011; Ritchie et al. 2011; Stoker et al. 2016).

The major rifting phase in the Faroe-Shetland region occurred during the Cretaceous (Mudge \& Rashid 1987; Dean et al. 1999; Lamers \& Carmichael 1999; Larsen et al. 2010), when this area developed as part of a broad zone of extension and subsidence that stretched for about 3000 km from the southern Rockall Basin to the western Barents Sea (Doré et al. 1999; Roberts et al. 1999). In the study area, the Faroe-Shetland Basin is the main expression of Cretaceous rifting and has accumulated up to $5 \mathrm{~km}$ of sediment; this contrasts with lesser, albeit locally substantial amounts (up to $2.5 \mathrm{~km}$ ) deposited in some of the peripheral outlying basins on its south-eastern margin, including the West Shetland Basin (Stoker \& Ziska 2011) (Fig. 2). The distribution of these rocks is well constrained on the basis of seismic reflection and well data along the eastern side of the Faroe-Shetland region, beyond the south-eastern limit of the Early Palaeogene breakup-related volcanic rocks. However, to the west of this limit the occurrence of Cretaceous rocks is inferred (Keser Neish \& Ziska 2005; Raum et al. 2005; Ritchie et al. 2011) due to a lack of well data and poor seismic definition beneath the volcanic rocks (Figs 1 \& 2). 
Despite significant interest in the Cretaceous development of the Faroe-Shetland region, there is still a lack of consensus with regard to tectonic style. It is arguable that in the early stages of exploration along the NW European margin, much initial confusion was driven by the import of a North Sea rift model whereby extensional tectonic models for the Jurassic were commonly extrapolated into the Early Cretaceous (Oakman \& Partington 1998). For example, in the Porcupine Basin (offshore SW Ireland) and on the Halten Terrace (offshore Mid Norway) - to the SW and NE of the Faroe-Shetland region, respectively - Late Jurassic and Early Cretaceous rifting phases are referred to as a single event (Blystad et al. 1995; McCann et al. 1995). The application of this model to the Atlantic margin of NW Europe was subsequently refuted on the basis of a considerable body of evidence assembled from along the entire length of the margin, including the Faroe-Shetland region, which demonstrated a clear distinction between Late Jurassic and Early Cretaceous rift events (Lundin \& Doré 1997; Dean et al. 1999; Doré et al. 1999). This distinction is based on the recognition of a regional Early Cretaceous hiatus, including within the Faroe-Shetland region, and which is described more fully in this paper.

There remain two outstanding issues that are important to our understanding of the tectonic style of the Faroe-Shetland region:

- The timing of onset of Early Cretaceous rifting: a variety of ages have been proposed, including late Berriasian (Booth et al. 1993), late Berriasian-Barremian (Turner \& Scrutton 1993), Valanginian (Grant et al. 1999), Valanginian-Barremian (Dean et al. 1999), Valanginian with intensification in the Aptian-Albian (Larsen et al. 2010) and Aptian-Albian (Goodchild et al. 1999). From a regional NW European context, Doré et al. (1999) proposed a Hauterivian age, whereas Coward et al. (2003) identified Valanginian-Hauterivian and Aptian-Albian phases of rifting. 
- Late Cretaceous tectonism: although this interval has been considered to be dominated by passive subsidence and relative tectonic quiescence (Hancock \& Rawson 1992; Harker 2002; Coward et al. 2003; Cope 2006), there is increasing evidence for tectonic activity persisting throughout the Late Cretaceous across the NW European margin (Lundin \& Doré 1997; Oakman \& Partington 1998; Doré et al. 1999; Roberts et al. 1999), including the Faroe-Shetland region where the effects of deformation ranging in age from Cenomanian to Maastrichtian have been reported (Booth et al. 1993; Dean et al. 1999; Goodchild et al. 1999; Larsen et al. 2010).

The seeming lack of consensus in the age of onset of Early Cretaceous rifting in the FaroeShetland region might be a reflection of the spatially restricted areas of study of the individual groups (cited above), which are commonly tied to specific basins. There is also the question of biostratigraphical resolution, especially in some of the coarse clastic facies that characterise the Lower Cretaceous succession (Stoker \& Ziska 2011). Alternatively, if the spread of ages between basins does represent spatial and temporal variation, this likely has consequences for the development of a Cretaceous tectonic model. The same reasoning applies to the timing and style of Late Cretaceous deformation across the Faroe-Shetland region, which has not previously been collectively reported, but forms an integral part of the structural and depositional system.

In an attempt to address these issues, this paper presents a regional appraisal of the Cretaceous succession in the Faroe-Shetland region. The main objective of the study is to establish a regional stratigraphical framework across the region at a scale that enables a firstorder analysis of its tectonostratigraphical development. To achieve this, the focus is on the identification and description of regionally ‘mappable’ depositional sequences, integrating all available geological and geophysical data. The latter includes an appraisal of the rock record provided by released commercial wells, which - when combined with seismic-stratigraphic 
97 information - is used to provide constraints on the varying ages, facies characteristics and sediment thicknesses preserved in basins across the region, which in turn may provide a clue as to the prevailing structural control on basin history.

\section{Structural setting}

The structural framework of the Faroe-Shetland region is dominated by the NE-trending Faroe-Shetland Basin, which is up to $400 \mathrm{~km}$ long and $250 \mathrm{~km}$ wide, and comprises a complex amalgam of 11 sub-basins generally separated from one another by NE-trending crystalline-basement-cored structural highs (Ritchie et al. 2011) (Figs 1 \& 2). This structural trend represents an inherited Caledonian tectonic grain, which is also expressed by major NEtrending basin-bounding faults, such as the Rona Fault (SE Faroe-Shetland Basin) and the Shetland Spine Fault (West Shetland Basin - see below). Where sub-basins within the FaroeShetland Basin are juxtaposed, their boundaries are somewhat equivocal (inferred structural boundaries on Fig. 1); either defined by the inferred continuations of the general trend of bounding basement highs, or the locations of possible NW-trending rift-oblique lineaments influenced by a pre-Caledonian structural grain (Rumph et al. 1993; Moy \& Imber 2009; Ritchie et al. 2011). The SW margin of the Faroe-Shetland Basin is bounded, in part, by the NW-trending Judd Fault, which is testament to the significance of this structural trend. Along its southern and south-eastern margins, the Faroe-Shetland Basin is separated from a suite of smaller NE-trending basins, including the West Shetland Basin and the East Solan, South Solan, West Solan and North Rona basins - herein collectively referred to as the SE Marginal Basins - by the basement-cored Rona and Judd highs. The West Shetland Basin and SE Marginal Basins all currently underlie the West Shetland Shelf (Figs 2 \& 3).

According to Ritchie et al. (2011), the Fugloy and Munkagrunnur ridges mark the northern and western boundaries, respectively, of the Faroe-Shetland Basin, with the Fugloy Ridge 
separating the basin from the Continent-Ocean Boundary (Fig. 1). Both these ridges are interpreted to consist of crystalline basement blocks capped by Mesozoic (including Cretaceous?) and/or early Cenozoic rocks (Smallwood et al. 2001; Raum et al. 2005; Ritchie et al. 2011). The present antiformal geometry of the ridges is inferred to have developed in response to later, post-breakup, contractional deformation and/or the effects of differential thermal subsidence particularly during the Eocene-Miocene interval (Johnson et al. 2005;

Ritchie et al. 2008). The transition of both ridges with the Faroe Platform is poorly understood. The north-eastern boundary of the Faroe-Shetland Basin is marked by the Møre Marginal High, which is probably comparable in composition to the Fugloy and Munkagrunnur ridges, and the Møre Basin (Brekke 2000).

The post-breakup tectonic movements enhanced the Fugloy and Munkagrunnur ridges as structural highs, and thus helped to create the contemporary bathymetry of the Faroe and West Shetland shelves, separated by the deeper-water Faroe-Shetland Channel (Fig. 2). The latter represents the present-day expression of the Faroe-Shetland Basin, albeit narrower as a consequence of the infilling of the wider Mesozoic basin by episodic shelf-margin progradation of both the Faroese and West Shetland margins throughout the Cenozoic (Stoker et al. 2005, 2010, 2013; Ólavsdóttir et al. 2013).

\section{Data and methods}

This study is based upon the vast wealth of geological and geophysical information acquired by the British Geological Survey over the last 50 years: initially as part of their regional offshore mapping programme undertaken between the early 1970s and the late 1990s; more

142 recently, over the last decade, in collaboration with Jarðfeingi (Faroese Earth and Energy

143 Directorate) and oil and gas industry partners, including the Faroe-Shetland Consortium 144 (FSC: see Acknowledgements). 
The rock record provided a significant basis for this study, which had access to 116 released commercial wells that are distributed widely throughout the eastern half of the FaroeShetland region (Fig. 1; Table 1). In the Faroe-Shetland Basin, this includes wells drilled in the Judd, Flett, Foula, Erlend and Yell sub-basins as well as on the Corona, Flett, Westray and Erlend intra-basinal highs. In the area outlying the Faroe-Shetland Basin, wells are located in the West Shetland Basin, in the SE Marginal Basins (i.e. East Solan, South Solan, West Solan and North Rona basins), and on intervening highs, such as the Solan Bank, Judd and Rona highs. These well data were previously described and incorporated into a set of stratigraphical-range charts by Stoker \& Ziska (2011), which detailed lithology, thickness and lithostratigraphy of each individual well against the chronostratigraphical range as reported from released well-logs and biostratigraphical reports or published data (e.g. Ritchie et al. 1996; Dean et al. 1999; Goodchild et al. 1999; Grant et al. 1999). The lithostratigraphical scheme shown on these charts, and utilised in this study, is from Ritchie et al. (1996) who described a series of groups - the Lower Cretaceous Cromer Knoll Group and the Upper Cretaceous Chalk and Shetland groups - and their component formations, which are summarised in Table 2. This lithostratigraphical scheme is based predominantly on the interpretation of wireline logs supplemented by biostratigraphical information. For more detailed lithological descriptions, the reader is referred to Ritchie et al. (1996) and Stoker \& Ziska (2011).

In this study, this dataset has been utilised to develop a revised set of stratigraphical-range charts that incorporate the information derived from the individual wells into a series of columns that represent and summarise the various basins, sub-basins and highs, i.e. each column is a summation of the information from all wells associated with a specific structural element (Figs 4 \& 5; Table 1). Whereas lithostratigraphical units and drilled thicknesses are retained on these charts, the lithological information is presented in terms of gross 
depositional environments. These differentiate between paralic, shelf and basinal settings, incorporating siliciclastic and carbonate rocks, as well as various clastic facies. It should be noted that water depth, particularly in basinal settings, remains an issue of uncertainty.

Numerous authors (e.g. Ziegler 1988; Cope et al. 1992; Knott et al. 1993; Coward et al. 2003; Pharoah et al. 2010) have presumed that a through-going deep-marine basin had existed in the Faroe-Shetland region since the Jurassic. However, a comprehensive account of the observational record - put together in the context of the entire NE Atlantic region - suggests that such putative reconstructions are largely without any robust foundation (Stoker et al. 2016). This issue will be considered further in the Discussion section.

A limited number of regional 2D seismic reflections lines made available by the FSC integrated with published information provided the basis for an appraisal of the seismic stratigraphy of the basins/sub-basins described in this paper (Figs $2 \& 3$ ). Summary descriptions of the seismic-stratigraphical characteristics of the infill of the various basins/sub-basins are presented in Table 3, from which a common set of seismic reflectors representing unconformities of regional extent - has been established (see below). The well database together with published information was utilised to calibrate these boundaries.

In the construction of the regional stratigraphical framework emphasis was placed on the identification of depositional packages bounded by regional (basin-wide) surfaces of discontinuity. The regional stratigraphical scheme (Fig. 6) represents the integration of the available lithostratigraphical and seismic-stratigraphical data. The seismic stratigraphy reveals that two main depositional sequences, herein labelled (in ascending stratigraphic order) as $\mathrm{K} 1$ and $\mathrm{K} 2$, are preserved in all of the basins considered in this study, and which are bounded top and bottom by regional unconformity surfaces (Figs $2 \& 3$ ). Whereas these two packages are of informal stratigraphical status, they represent physically mappable unconformity-bounded units across the entire Faroe-Shetland region, and can be classed as 
megasequences as defined by Hubbard et al. (1985). The gross stratigraphical characteristics of the megasequences in the various basins are summarised in Table 3 . The bounding unconformities that define these two megasequences are informally referred to as the BaseCretaceous Unconformity (BCU), ‘Mid’ Cretaceous Unconformity (MCU) and Base Tertiary Unconformity (BTU). The MCU may be broadly equivalent to the 'Near Base Upper Cretaceous’ reflector shown by Lamers \& Carmichael (1999; their Fig. 5), but nowhere defined by them. Correlation of these key boundaries with the lithostratigraphy indicates that the K1 megasequence incorporates the Cromer Knoll and Chalk groups, as well as the lower part of the Shetland Group (Cenomanian-Turonian), whereas the K2 megasequence comprises the post-Turonian rocks of the Shetland Group. Smaller-scale units equivalent to the lithostratigraphical formations defined by Ritchie et al. (1996) can be identified locally in individual basins/sub-basins (e.g. Goodchild et al. 1999; Grant et al. 1999; Larsen et al. 2010), though widespread identification and regional correlation at formation level remains ambiguous.

\section{Cretaceous stratigraphical framework}

The geometry, structural disposition and stratigraphical range of the Cretaceous succession are depicted in Figures 2-5, with the key elements of the regional integrated stratigraphic framework summarised in Figure 6. Inspection of the regional geoseismic profiles in Figure 2 highlights a key observation that the distribution and thickness of the K1 megasequence within the Faroe-Shetland Basin are highly variable, and do not display the blanket-style cover displayed by the thicker K2 megasequence, although the latter also thins, and is locally absent, above intra-basinal and bounding highs. The main elements (megasequences and bounding unconformities) of the Cretaceous stratigraphical framework are summarised below, in ascending stratigraphic order. 
220 On seismic profiles, the BCU is marked by a moderate-amplitude reflection that represents a

221 widespread erosional boundary (Lamers \& Carmichael 1999) (Figs 2 \& 3). Well data indicate that this boundary marks the base of the Cromer Knoll Group, which overlies a range of truncated older rocks, including Upper Jurassic-lowest Cretaceous (Humber Group), Lower Jurassic, Permo-Triassic, Devono-Carboniferous and undifferentiated Palaeozoic and Precambrian strata (Figs $4 \& 5$ ). The time gap represented by this unconformity is variable, ranging from intra-Berriasian in some of the SE Marginal Basins, and the SW West Shetland Basin, to $>10$ My in the Faroe-Shetland Basin where most of the pre-Aptian record seems to be missing (Fig. 6). In the North Rona and East Solan basins, several intra-Early Cretaceous breaks of Valanginian and Hauterivian age are preserved. These local unconformities together with the fragmentary record of pre-Aptian rocks in other parts of the Faroe-Shetland region (Figs $4 \& 5$ ) imply that a low level of background tectonic activity might have prevailed in the early part of the Cretaceous. This might also indicate that in those areas where much of the pre-Aptian record is missing the BCU does not necessarily represent a single event of transgression (Harker 2002).

K1 megasequence

Age range and internal stratigraphy:

The K1 megasequence represents a duration of about 50 myr (late Berriasian-Turonian) (Fig. 6), though sedimentation was not continuous throughout this interval. In the West Shetland Basin and the SE Marginal Basins, the megasequence comprises the Cromer Knoll and the Chalk groups. The Lower Cretaceous

240 Cromer Knoll Group is divided into the argillaceous Valhall (late Berriasian-early Aptian),

241 Carrack (Aptian-Albian) and Rødby (Albian) formations and the laterally equivalent coarse clastic Victory Formation. The argillaceous formations dominate the SE Marginal basins, and 
well-log data from the North Rona and East Solan basins show that the drilled succession in these basins is $100-300$ m thick and punctuated by a series of unconformities correlated to the Valanginian, Hauterivian, and Aptian/Albian stages (Stoker \& Ziska 2011) (Fig. 4). Although the available well data from the South Solan and West Solan basins appear to show a more fragmentary record of sedimentation, seismic reflection profiles indicate that a sequence of comparable thickness might be present in these basins (Booth et al. 1993) (Fig.

3a). The Victory Formation dominates the West Shetland Basin. A more continuous record of late Berriasian-Albian sedimentation is preserved in the SW part of this basin, where maximum-drilled thicknesses exceed 1 km (Stoker \& Ziska 2011). However, the Victory Formation is thinner in the NE part of the basin where the bulk of the preserved rocks are of Aptian/Albian age (Fig. 4). The Victory Formation has also been recognised on parts of the Rona High, though it is commonly absent over the crest of the high (Stoker et al. 1993).

The overlying Chalk Group includes the Hidra and Herring formations of CenomanianTuronian age (Ritchie et al. 1996) (Fig. 4). The Hidra Formation includes the Haddock Sandstone Unit in the West Shetland Basin, whereas the base of the Herring Formation is marked by the Black Band (bed status) in the North Rona and West Shetland basins, though this bed has also been recognised in the Macbeth Formation (see below). In the SE Marginal Basins, the Chalk Group is separated from the Cromer Knoll Group by an

Albian/Cenomanian unconformity, though a more continuous transition characterises the SW West Shetland Basin. A maximum-drilled thickness of $250 \mathrm{~m}$ is recorded from the SW West Shetland Basin (Stoker \& Ziska 2011), whereas the Chalk Group is not recognised in the NE West Shetland Basin, where much of the Cenomanian-Turonian interval is marked by a hiatus (Goodchild et al. 1999). 
Neptune, Royal Sovereign and Commodore formations, as well as the Phoebe Sandstone

Unit, have been defined (Fig. 6). The latter sandstone unit is interbedded with the Cruiser

Formation, but is probably equivalent to, albeit geographically separated from, the

271

Commodore Formation. Significantly, the basal age of the sediment fill in the Faroe-Shetland Basin is Aptian (possibly latest Barremian) (Fig. 5). Although the Commodore Formation extends into the Cenomanian it is included within the Cromer Knoll Group, as the bulk of the deposits are believed to be of Albian age (Ritchie et al. 1996). Maximum-drilled total sediment thicknesses exceed $1 \mathrm{~km}$ in the Flett and Foula sub-basins (Stoker \& Ziska 2011) (Fig. 5). By way of contrast, the Chalk Group is replaced to the north and west (in the FaroeShetland Basin) by the Svarte and Macbeth formations of the Shetland Group, which commonly exceed a combined drilled thickness of $500 \mathrm{~m}$. Although there is no evidence for a physical connection (lateral transition) between these groups, the recognition of the Black Band in both the Herring and Macbeth formations, including across the Rona and Westray highs, confirms their correlation (Ritchie et al. 1996) (Figs 4 \& 5).

Depositional environment: The K1 megasequence is characterised by paralic and mixed siliciclastic and carbonate shelf and basinal facies, with variable coarse clastic deposits, including basal conglomerates and mass-flow deposits (Figs 4 \& 5). In the West Shetland Basin, the Lower Cretaceous Victory Formation consists of a thick succession of paralic to shallow-marine sandstones and conglomerates with coals locally present (Ritchie et al. 1996; Harker 2002; Stoker \& Ziska 2011) (Fig. 4; Table 2). The Victory Formation displays an overall wedge-shaped geometry (Table 3) that thickens into the basin-bounding West Shetland Spine Fault, though Goodchild et al. (1999) recognise a parallel-bedded unit of fairly constant thickness at the base of the wedge that comprises fan-delta and shoreface deposits, which are overlain and onlapped by shoreface to inner shelf sediments that form the bulk of the wedge. The available well data suggest that the NE part of the West Shetland 
Basin did not become a significant depocentre until the Aptian/Albian, whereas activity in the SW part of the basin began much earlier (Fig. 4).

The Lower Cretaceous Valhall, Carrack and Rødby formations comprise variably calcareous to non-calcareous marine mudstones with sporadic thin limestones and sandstones (Ritchie et al. 1996; Harker 2002; Stoker \& Ziska 2011) (Table 2). The Valhall and Rødby formations were deposited under aerobic marine shelf conditions whereas the Carrack Formation was deposited in a more restricted anoxic basin with bottom-water oxygen depletion. The punctuated record of mudstone-dominated deposition may be a consequence of low-level background tectonic activity in the early part of the Cretaceous. The increase in coarser clastic input following some of these hiatuses might be indicative of local fault activity and rejuvenated source areas. Individual formations have not been differentiated on seismic profiles across the SE Marginal Basins and the Cromer Knoll Group deposits as a whole display low-angle onlap onto the rocks underlying the BCU (Fig. 3; Table 3).

In the Faroe-Shetland Basin, marine-mudstone deposition in the Judd, Flett and Foula subbasins began later (in the latest Barremian/Aptian) compared with the SE Marginal Basins (Figs 5 \& 6). The Valhall, Carrack and Rødby formations are variably present in the Judd and Flett sub-basins, whereas the equivalent mudstones in the Foula sub-Basin belong solely to the Cruiser Formation, which preserves a comparable record of aerobic/anaerobic bottomwater fluctuation (Table 2). The accumulation of marine mudstone was accompanied by the deposition of coarse clastic rocks of the Neptune, Royal Sovereign and Commodore formations, which interdigitate with the mudstone facies on the flanks of the Faroe-Shetland Basin, adjacent to the Rona and Judd highs, as well as the intra-basinal Flett and Westray highs (Ritchie et al. 1996; Grant et al. 1999) (Fig. 6). These coarse clastic rocks have been interpreted as proximal marine slope or fan assemblages deposited by gravity flow processes (Ritchie et al. 1996; Harker 2002) and, together with the mudstone deposits, are preserved as 
asymmetric wedges associated with half-graben development (Grant et al. 1999; Lamers \&

319 Carmichael 1999; Ritchie et al. 2011) (Fig. 2; Table 3). Although these coarse clastic rocks are generally assumed to have been deposited in 'deeper' water than those of the Victory Formation (e.g. Ritchie et al. 1996; Lamers \& Carmichael 1999; Harker 2002), the evidence

322 for this assumption is equivocal (see Discussion).

The Upper Cretaceous Chalk Group succession comprises cryptocrystalline limestones interbedded with argillaceous limestones and mudstones, which accumulated for the most part in a well-oxygenated marine shelf setting (Ritchie et al. 1996) (Table 2). The arenaceous clastic rocks of the Haddock Sandstone Unit accumulated in the SW part of the West Shetland Basin, and were probably derived from the adjacent West Shetland High. These sandstones might be correlatable, in part, with the Commodore Formation in the FaroeShetland Basin. To the north and west, the equivalent Svarte and Macbeth formations of the Shetland Group are composed of calcareous mudstones with interbedded limestone and sporadic siltstone and sandstone, which were deposited on a generally aerobic shelf. The Black Band at the base of both the Herring and Macbeth formations was deposited during an interval when bottom waters across the region became temporarily stagnant and anoxic (Johnson \& Lott 1993).

Not all well logs record the MCU unconformity; however, seismic profiles commonly display a high-amplitude reflection (or set of reflections) variously expressed as: a planar- to synformally-disposed surface (e.g. North Rona Basin; West Shetland Basin; Foula sub-Basin; Judd sub-Basin); an irregular erosion surface (e.g. West Solan Basin); or a faulted and folded surface (e.g. East Solan Basin) (Figs 2 \& 3). On the flanks of some basins (e.g. West Shetland Basin), erosion has been linked to footwall uplift during the late Albian-late Coniacian 
342 (Goodchild et al. 1999). It is acknowledged that the identification of this boundary is based on a long-standing seismic-stratigraphic observation (e.g. Duindam \& van Hoorn 1987; Hitchen \& Ritchie 1987; Mudge \& Rashid 1987); however, in these publications the boundary was commonly shown to separate Lower and Upper Cretaceous rocks. More recent detailed stratigraphic work has shown that the strongly reflective character of the boundary lies within the Upper Cretaceous, and can be correlated with sandstones and limestones of Cenomanian-Turonian/Coniacian age, which are characteristically onlapped by Senonian (Coniacian-Campanian) rocks (Booth et al. 1993; Goodchild et al. 1999; Grant et al. 1999; Lamers \& Carmichael 1999; Larsen et al. 2010) (Figs 4 \& 5). In several basins, such as the West Solan and South Solan basins, the lower part of the Upper Cretaceous succession is absent and the MCU does effectively mark the Lower/Upper Cretaceous boundary (Fig. 6).

K2 megasequence about 23 myr (latest Turonian/Coniacian-Maastrichtian) though sedimentation only became generally widespread during the Campanian-Maastrichtian (Figs 4-6). The megasequence comprises the bulk of the Shetland Group; specifically the argillaceous Kyrre (latest Turonian-mid/late Campanian) and Jorsalfare (mid/late Campanian-Maastrichtian) formations (Fig. 6; Table 2). In the Kyrre Formation, localised sandstone- and limestone-rich facies preserved in the West Shetland Basin have been assigned to the Whiting Sandstone and Dab Limestone units, respectively (Ritchie et al. 1996). Well-log data indicate that the drilled succession commonly exceeds $500 \mathrm{~m}$ in thickness across the region, with a maximum-drilled thickness up to $2.5 \mathrm{~km}$ thick in the South Solan Basin (Figs 4 \& 5). In contrast, a thickness up to $4.5 \mathrm{~km}$ has been estimated for the K2 megasequence in the Flett and Foula sub-basins on the basis of seismic data (Lamers \& Carmichael 1999). 
In the SW part of the West Shetland Basin and in the SE Marginal Basins, the well and seismic data reveal the significant hiatus between the K1 and K2 megasequences that marks the MCU, with much of the Coniacian-Santonian (and locally the Cenomanian-late Campanian) record missing (Figs 3 \& 4). Whereas well-log data (available to this study) in the NE West Shetland Basin imply a continuous Coniacian-Maastrichtian infill (Fig. 4), it is clearly observed on seismic data that this succession is cut by a late Campanian unconformity. Upper Campanian-Maastrichtian sediments - essentially the Jorsalfare Formation - overlie the unconformity, onlapping and infilling the space created by a synformally-disposed Kyrre Formation (Goodchild et al. 1999). Consequently, the longranging hiatus that punctuates the Upper Cretaceous succession in the SW West Shetland and North Rona basins might represent a composite 'Mid’ Cretaceous/late Campanian unconformity (Fig. 4).

On regional seismic profiles, variations in the thickness of the K2 megasequence basin-fill are observed across the main basin-bounding faults of the West Shetland Basin, East Solan Basin and the Judd, Flett and Foula sub-basins (Fig. 2; Table 3). The preservation of thick sequences preserved in the hanging-walls of these basins, which are juxtaposed against Triassic and older rocks, has been attributed by Dean et al. (1999) to active faulting along the basin-bounding faults, including the Shetland Spine Fault and the Rona Fault.

In the Faroe-Shetland Basin, the internal seismic character of the K2 megasequence is commonly obscured by high-amplitude reflections associated with Paleocene sills that have intruded large parts of the basin fill (Fig. 2). Although the megasequence can be described in general terms as having a blanket-style geometry across the basin, there are indications of thickness variations adjacent to and across intra-basinal highs; an observation that is further enhanced by the well-log data from the Faroe-Shetland Basin (Fig. 5). There is no doubt that the Flett and Foula sub-basins, in particular, preserve thick accumulations of Coniacian- 
Maastrichtian sediment; however, the apparent continuity of sedimentation indicated on the well-log data should be viewed with caution given that Goodchild et al. (1999; their Fig. 4) have shown that the late Campanian unconformity extends across the north-eastern part of the Rona High and into the Foula sub-Basin. Indeed, Grant et al. (1999) also note an 'End Campanian seismic marker’, though they do not present any further detail regarding this surface. Evidence for an 'anything but continuous’ infill history is especially evident in wells from the Judd sub-Basin and the intra-basinal Westray and Corona highs where there are significant gaps in the record (Fig. 5). Of particular note is the contrast between the Westray and Corona highs where much of the Campanian-Maastrichtian record is absent, and the Flett High where a more complete succession has been preserved. The occurrence of some Maastrichtian sediment on the Westray High implies that it was either subjected to contemporary erosion during the Late Cretaceous or that it was a largely emergent high (at or near sea-level) during the Campanian-Maastrichtian (Dean et al. 1999).

404

Overall, the stratigraphic record indicates that Late Cretaceous sedimentation was most regionally extensive during the Campanian-Maastrichtian (Figs 4 \& 5). Notwithstanding the uncertain spatial and temporal extent of the late Campanian unconformity, the Rona High became largely submerged during this interval.

Depositional environment: The K2 megasequence is characterised by a marine mudstone facies with sporadic limestone and sandstone deposits (Figs 4 \& 5; Table 2). Compositional variation within the mudstone succession is largely a reflection of the carbonate content, with the Kyrre Formation dominated by non-calcareous agglutinated foraminifera indicative of a relatively restricted marine environment, whereas an abundance of planktonic foraminifera in the Jorsalfare Formation attests to a more fully oxygenated and open marine setting (Ritchie et al. 1996; Harker 2002). Water depth throughout the deposition of the K2 megasequence 
remains equivocal, as the foraminifera are non-diagnostic and range between sub-littoral to bathyal marine settings (Ritchie et al. 1996), i.e. coastal to deep-water (to $2000 \mathrm{~m}$ ) settings.

417 The general absence of Coniacian-Santonian deposits from the SE Marginal Basins, adjacent highs, and parts of the Rona High suggests that a partially emergent shallow-marine platform, including islands, bordered the SE margin of the Faroe-Shetland Basin at this time. This is consistent with the deposition of the Dab Limestone and Whiting Sandstone units of the Kyrre Formation (Table 2), which has been attributed to a marine shelf setting for both these units within the West Shetland Basin (Meadows et al. 1987; Ritchie et al. 1996). In contrast, the general widespread deposition of Campanian-Maastrichtian rocks in the Faroe-Shetland region indicates a gradual drowning of the land area. This is commonly associated with a regional Late Cretaceous marine transgression driven by a high eustatic sea level (Hancock \& Rawson 1992; Harker 2002; Cope 2006), though considerable uncertainty remains concerning palaeogeography and processes. Certain areas within the Faroe-Shetland Basin (e.g. Westray High, Corona High) that had been depocentres in the Coniacian-Santonian may have become palaeo-highs (islands?) in the Campanian-Maastrichtian. At the same time, thick sequences of marine mudstone accumulated in the hanging-walls of a number of basins adjacent to major faults, including the West Shetland Spine Fault and the Rona Fault. In the absence of evidence for coarse clastic input, the derivation of the argillaceous sediment remains unknown.

Base Tertiary Unconformity (BTU)

The BTU is marked by a moderate- to high-amplitude reflection on seismic profiles that corresponds primarily to an erosional boundary - as recorded in most wells - that truncates the Cretaceous succession and is commonly onlapped by Paleocene and younger strata, though a locally conformable transition cannot be discounted (Lamers \& Carmichael 1999) 
439 (Figs 2-5). In the East Solan and West Solan basins, the unconformity might be linked to

440 latest Cretaceous/earliest Paleocene inversion (Booth et al. 1993) driven by the

441 transpressional reactivation of major NE-trending faults, such as the Rona Fault (Goodchild 442 et al. 1999).

\section{Discussion}

444 Any attempt to understand the Cretaceous stratigraphical and sedimentological development of the Faroe-Shetland region has to take into consideration its regional tectonic setting (Fig. 7). Megasequence development and regional unconformities (megasequence boundaries) tend to reflect major phases of basin evolution, commonly in response to regional tectonic events that modified patterns of sedimentation (Hubbard et al. 1985). On the scale of a continental margin, plate-tectonic processes most probably drive such changes. During the Cretaceous, the Faroe-Shetland region was located in the central part of Laurasia and within the developing NE Atlantic rift system (Fig. 8). This was a significant time in the breakup of Pangaea with the onset of the closure of Tethys and the northward propagation of Atlantic rifting and sea-floor spreading influencing the development of the southern margin of Laurasia, whereas the instigation of the Amerasian Basin in the Arctic region imposed tectonic constraints on its northern margin (Ziegler 1988; Doré et al. 1999; Grantz et al. 2011). Consequently, it is highly probable that the proto-NE Atlantic region in general, and the Faroe-Shetland region in particular, was subjected to a complex pattern of stress orientations throughout the Cretaceous (Figs 7 \& 8).

The stratigraphical and sedimentological observations presented here provide a basis upon which to assess the tectonic effects on the Cretaceous succession in the Faroe-Shetland region. In the following sub-sections, a summary of the tectonostratigraphical framework is presented, which correlates key aspects of the stratigraphy and sedimentology with both local 
463 (Faroe-Shetland) and regional (North Atlantic-western Europe) tectonic events; the latter set

464 within the context of Laurasia (Fig. 8). This framework is combined with a series of schematic palaeogeographical maps (Fig. 9) that have been developed in order to present both the temporal and spatial evolution of the Faroe-Shetland region. Sediment thicknesses and accumulation rates based on drilled sections are also presented to aid the description (Fig 7;

Table 4). The accumulation rates should be regarded as a minimum rate as they are based on drilled sections only and undecompacted rock thicknesses; nevertheless, the regional extent of the dataset provides a valid insight into the evolving sedimentary system.

Tectonostratigraphical framework

The two-fold megasequence framework (K1 and K2) provides a clear basis for establishing the regional first-order stratigraphical and tectonic setting of the Cretaceous succession in the Faroe-Shetland region. Notwithstanding the clear bipartite division of the Cretaceous as observed on seismic reflection profiles in terms of regional geometry and extent (Figs $2 \& 3$ ), the distinction between the K1 and K2 megasequences is also soundly based on several other criteria, including a change in gross lithofacies character, sediment thickness and accumulation rate (Fig. 6; Table 4). The megasequences are separated by the MCU, which is an unconformity that represents the sedimentary response to a regional change in basin geometry in the early Late Cretaceous. In general terms, this change is most clearly expressed by the marked increase in thickness and extent of the K2 megasequence across the FaroeShetland Basin (Fig. 2), which is most probably associated with a significant enlargement of the basin. However, the rock record summarised in this paper indicates that this basin development was not a simple two-stage process. The evidence for intermittent uplift and erosion documented by numerous previous workers - as described above - suggests that the pattern of Cretaceous basin development did not fit a simple rift model. As stated by Dean et 
region varied with time, from which they so eloquently concluded that 'uplift and subsidence within the Cretaceous period was thus highly variable and a single, discrete rift model (that implies a predictable subsidence history throughout the basin) is inappropriate'.

Thus, to fully understand the tectonic history of the region it is important to consider the stratigraphical framework in terms of higher-order depositional sequences that more accurately reflect the punctuated record preserved within the megasequences (Figs 4-6). On this basis, megasequences K1 and K2 have collectively been broadly subdivided into five second- to third-order depositional packages, which are indicated on Figure 7 as discrete 'sediment pulses'. These sediment pulses essentially span the following time intervals in ascending stratigraphic order: a) late Berriasian-Barremian; b) Aptian-Albian; c)

Cenomanian-Turonian; d) Coniacian-Santonian; and, e) Campanian-Maastrichtian.

Arguably, the latter could be split into early Campanian and late Campanian-Maastrichtian, separated by the late Campanian unconformity; however, this is beyond the limit of biostratigraphic resolution available for this study. These five intervals have been utilised to construct a series of schematic palaeogeographical maps (Fig. 9) to illustrate the Cretaceous development of the Faroe-Shetland region. These maps are based on what is currently known; however, it is recognised that the lack of information from the western side of the region imposes constraints upon any conclusions drawn from the reconstructions. As an aid to addressing this uncertainty, observations from the surrounding, wider geographic area are incorporated into the map descriptions, which are summarised below.

Late Berriasian-Barremian:

Figure 9a depicts the Faroe-Shetland region following Late Jurassic-earliest Cretaceous uplift and erosion, which instigated the formation of the BCU. During the late Berriasian-Barremian interval, proven active basin development is largely restricted to the East Solan and North Rona basins, which form part of the SE Marginal Basin domain, and the SW West Shetland Basin, though sporadic deposition is also 
recorded from the South Solan Basin and the NE West Shetland Basin (Fig. 4). The SW West

514 Shetland Basin accumulated a thick sequence of paralic and sandy shallow-marine deposits of the Victory Formation adjacent to the Shetland Spine Fault (Ritchie et al. 1996; Harker 2002; preserve a thinner record of mixed siliciclastic and carbonate shallow-marine deposition, assigned to the Valhall Formation (Ritchie et al. 1996), which is punctuated by intra-

Valanginian and Hauterivian hiatuses. Maximum-drilled sediment thicknesses indicate that the SW West Shetland Basin accumulated at least 5 times more sediment than any of the adjacent basins (Table 4). Whereas the average sediment accumulation rate across all basins was $8.2 \mathrm{~m} \mathrm{Ma}^{-1}$ (Fig. 7), the specific rate for the SW West Shetland Basin was $51 \mathrm{~m} \mathrm{Ma}^{-1}$

523 (Table 4). This suggests that the Shetland Spine Fault was the most active of the faults at this time, with more intermittent (as indicated by the hiatuses), smaller-scale movements on the faults bounding the North Rona and East Solan basins.

These paralic to shallow-marine basins appear to have been relatively isolated within a largely exposed hinterland that covers much of the West Shetland region. In particular, the Orkney-Shetland High, Rona High, West Shetland High and North Shetland High might have acted collectively as a barrier (perhaps even a watershed) between the West Shetland Basin and SE Marginal Basins and the larger North Sea Basin to the east. Farther west, the exposed area extends at least as far as the Judd High-Outer Hebrides High, which imparts a marked offset in the palaeogeography of the hinterland.

The southern and eastern flanks of the Faroe-Shetland Basin, including the Judd sub-Basin, the SE margin of the Flett and Foula sub-basins, and the Yell sub-Basin were also emergent, as were the intra-basinal Westray and Corona highs, possibly the Flett High, as well as much of the Erlend High (Larsen et al. 2010; Stoker \& Ziska 2011). The likelihood of pre-Aptian 
rocks in the deeper axial parts of the Foula and Flett sub-basins cannot be discounted, though information on pre-Aptian Cretaceous rocks is lacking from these locations.

539 According to Ritchie et al. (1996), the mudstones of the Valhall Formation in the Faroe540 Shetland region were deposited in a predominantly aerobic environment, which implies a 541 relatively open water circulation and, thus, a connection with adjacent areas. However, the 542 degree of connectivity with the wider geographic realm remains unclear on the basis of the 543 following observations: 1) to the NW, the conjugate SE Greenland margin, specifically the 544 Kangerlussuaq-Blosseville Kyst region (Fig. 8), was exposed at this time (Larsen et al. 1999a, b; Stoker et al. 2016); 2) to the SW, a hiatus in the North Lewis and North Minch basins suggests that there was no connection via the Hebridean region to the Erris or southern Rockall basins, which were open at this time (Stoker et al. 2016), whereas the North Rockall and West Lewis basins were probably not active until the late Barremian/early Aptian (Musgrove \& Mitchener 1996; Smith 2013) (Figs 1 \& 8); 3) east of Shetland, shallow-marine clastics recovered from the Unst Basin (Stoker \& Ziska 2011) are interpreted by Copestake et al. (2003) as indicative of an extensive mixed clastic and carbonate shelf, flanking the semiemergent western margin of the Viking Graben (Fig. 8), whereas Harker (2002) proposed that the East Shetland High was exposed; and, 4) to the NE, the SW Møre Basin and the Magnus Basin (Figs 1 \& 8) were not actively accumulating sediment until the late Hauterivian

555 (Copestake et al. 2003; Stoker and Ziska 2011).

Aptian-Albian: $\quad$ The onset of a significant change in the basinal development of the

557 Faroe-Shetland region is evident in this interval, with the rock record suggesting that the 558 Faroe-Shetland Basin became a larger, more integrated depocentre (Fig. 9b). The Judd, Foula and Flett sub-basins accumulated predominantly marine mudstones of the Valhall, Carrack,

560 Cruiser and Rødby formations, fringed by coarse clastic deposits, including basal

561 conglomerate and mass-flow sandstones, of the Commodore, Royal Sovereign and Neptune 
formations (Ritchie et al. 1996; Harker 2002; Stoker and Ziska 2011) (Figs 5 \& 6). The previously emergent Corona and Westray intra-basinal highs were drowned and buried beneath a cover of marine mudstone. The NE and SW ends of the Rona High also record a sediment cover at this time; however, the bulk of the high remained exposed. On the NE flank of the Faroe-Shetland Basin, the Yell sub-Basin and Muckle Basin were probably also instigated at this time (Larsen et al. 2010), along with increased development of the NE West Shetland Basin. To the SW, paralic to shallow-marine deposition persisted within the SW West Shetland Basin, and marine mudstone accumulated in the SE Marginal Basins, though the preserved record in the North Rona, West Solan, South Solan and East Solan basins is sporadic and commonly punctuated with hiatuses (Fig. 4). By way of contrast, the major hinterland areas of the Orkney-Shetland High, West Shetland High and North Shetland High persisted, as did the Judd High-Outer Hebrides High.

Maximum-drilled sediment thicknesses highlight this shift in basin development, with the Flett and Foula sub-basins, in particular, accumulating over $1 \mathrm{~km}$ of Aptian-Albian sediment and displaying sediment accumulation rates of 44-47 $\mathrm{m} \mathrm{Ma}^{-1}$ (Table 4). These thicknesses and accumulation rates strongly hint at major fault movement along the Rona Fault, and probably the Judd Fault at this time. The high accumulation rate in the Flett and Foula subbasins contrasts with a lower average basinal accumulation rate of $13.3 \mathrm{~m} \mathrm{Ma}^{-1}$, though the latter does mark an overall increase across the Faroe-Shetland region (Fig. 7). Whereas the accumulation rate is much reduced in the SW West Shetland Basin compared to the preAptian interval, the increased deposition in the NE West Shetland Basin implies that the Shetland Spine Fault might have been active along a greater proportion of its length. The relatively thin and punctuated sequences in the SE Marginal Basins imply that fault activity in this area remained intermittent and of a smaller-scale. 
One area of uncertainty concerns the genetic interpretation of the basal coarse clastic rocks that comprise the Neptune, Royal Sovereign and Commodore formations, and which fringe the Judd, Flett and Foula sub-basins. For example, Ritchie et al. (1996) have assigned both shallow- and deep-marine environments to the Neptune Formation, solely on the basis of its gamma-ray signature. Whereas it is acknowledged that well-logs provide important information on sand-body geometry, it is unclear to the present author how water depth can be derived solely from such data. A comparable ongoing controversy concerns the interpretation of a basal coarse clastic unit within the Upper Jurassic Kimmeridge Clay Formation in the SE Faroe-Shetland Region, for which both deep-water fan (Haszeldine et al. 1987; Hitchen \& Ritchie 1987) and subaerial-shallow-marine fan delta (Verstralen et al. 1995) depositional settings have been proposed.

597 The deposition of the Valhall, Carrack, Cruiser and Rødby formations occurred under fluctuating oxic/anoxic conditions (Ritchie et al. 1996), which suggests that marine connections between the Faroe-Shetland region and adjacent areas continued to be restricted to some degree. The basins in the SE part of the region might have been most restricted as there remained no obvious link through the Hebridean region to the open depocentres of the Erris and southern Rockall Basin (Harker 2002; Stoker et al. 2016) (Fig. 8). Marine mudstone was deposited in the West Lewis and North/NE Rockall basins at this time (Musgrove \& Mitchener 1996; Smith 2013), though these basins were separated from each other by the West Lewis High, and both were probably separated from the Faroe-Shetland Basin by the Judd High-Outer Hebrides High (Mudge \& Rashid 1987) (Figs 1, 8 \& 9b). The conflicting interpretations - as described above - regarding the degree of exposure of the western flank of the North Sea Basin, i.e. the East Shetland High (Harker 2002; Copestake et al. 2003) maintains ambiguity over any potential E-W linkage across the Orkney-Shetland hinterland. 

instigated and preserves a record of late Aptian-Albian paralic sedimentation and subsequent marine transgression (Larsen et al. 1999a, b; Nohr-Hansen 2012; Stoker et al. 2016).

Albian/Cenomanian boundary is marked by an erosional hiatus in the SE Marginal Basins, in the NE West Shetland Basin and on the Rona High (Figs 4 \& 6), which implies widespread uplift and/or exposure of the Orkney-Shetland hinterland. In the Faroe-Shetland Basin, the northern part of the Westray High (Fig. 5) was also exposed at this time. Although sedimentation resumed in the North Rona and East Solan basins in the following Cenomanian-Turonian interval, much of the Rona High and parts of the NE West Shetland Basin remained exposed (Fig. 9c).

In the Late Cretaceous, the Faroe-Shetland region was located at the northern limit of deposition of the Chalk Group (Harker 2002). Whereas limestone of the Hidra and Herring formations have been reported from the SW West Shetland, North Rona and East Solan basins, the bulk of the Cenomanian-Turonian sequence comprises calcareous mudstone of the Svarte and Macbeth formations of the mudstone-dominated Shetland Group (Ritchie et al. 1996; Harker 2002; Stoker \& Ziska 2011) (Figs 6 \& 9c). Localised coarse clastic rocks are associated with the Haddock Sandstone unit (part of the Hidra Formation) adjacent to the Shetland Spine Fault, and the mass-flow deposits of the Commodore Formation instigated in the Albian continued to accumulate on the eastern flank of the Faroe-Shetland Basin. The Orkney-Shetland hinterland and Judd High-Outer Hebrides High remained expansive. unit are most probably indicative of fault activity along the Judd, Rona and Shetland Spine faults. Maximum-drilled sediment thicknesses in the Judd, Flett and Foula sub-basins exceed 
$0.5 \mathrm{~km}$ for the Cenomanian-Turonian interval, and sediment accumulation rates ranging from 49-76 m Ma ${ }^{-1}$ are measured from these sub-basins (Table 4). Lower accumulation rates are measured from the West Shetland Basin, though the rates of $9.4 \mathrm{~m} \mathrm{Ma}^{-1}$ in the NE to $23.4 \mathrm{~m}$ $\mathrm{Ma}^{-1}$ in the SW both represent an increase on the Aptian-Albian accumulation rates. The average basinal accumulation rate across the region is $25.7 \mathrm{~m} \mathrm{Ma}^{-1}$, which is almost twice the average rate for the Aptian-Albian (Fig. 7).

Whereas the increased sediment accumulation rate might be indicative of an intensification of extensional fault activity, there is also evidence of contemporary compressional tectonics across the region (Fig. 9c), including: 1) Turonian folds in the Foula sub-basin (Grant et al. 1999); 2) latest Cenomanian-Turonian inversion (flower structure) in the East Solan Basin (Booth et al. 1993); and, 3) folding and erosion of Albian-Turonian sediments in the North Rona and West Solan basins (Fig. 3), though the timing of deformation is less precise (Turonian-early Campanian). Synformally-disposed surfaces at the Cenomanian-Turonian level are also observed in the West Shetland Basin and the Judd sub-Basin. This deformation is inextricably linked to the creation of the MCU, and might be a consequence of differential uplift and subsidence (sagging) during the proceeding phase of basin enlargement (see below).

In terms of the wider geographic area, a link between the SE Marginal Basins and the Inner Hebridean region during the Turonian has been suggested (Harker 2002). Tectonic activity in the Inner Hebrides region is regarded by Mortimore et al. (2001) and Emeleus \& Bell (2005) as a precursor to the deposition of the Upper Cretaceous Inner Hebrides Group, comprising shallow-marine sandstones and carbonate rocks comparable with the preserved sequences in the SW West Shetland Basin and the SE Marginal Basins. Marine mudstone deposition in the Kangerlussuaq Basin of SE Greenland, and the West Lewis and North and NE Rockall basins might be indicative of increasing inter-basinal connectivity with the Faroe-Shetland Basin in 
660

661

662

663

664

665

666

667

668

669

670

671

672

673

674

675

676

677

678

679

680

681

682

683

this part of the developing NE Atlantic rift zone (Fig. 8), though this does not necessarily imply a single through-going rift basin (see below). The Orkney-Shetland hinterland probably remained a barrier to E-W connection with the North Sea Basin (Harker 2002).

\section{Coniacian-Santonian: A major uncertainty during this interval is the extent of the} hinterland (Fig. 9d). Various authors (e.g. Hancock \& Rawson 1992; Harker 2002; Cope 2006) have suggested that regionally only remnants of the Scottish Highlands and Southern Uplands remained exposed during the Coniacian to Maastrichtian, and commonly show the Orkney-Shetland hinterland to be wholly submerged. This interpretation is largely predicated on the basis of a high eustatic sea level throughout the Late Cretaceous (Fig. 7). However, this contradicts the evidence from wells in the area of the SE Marginal Basins and the Rona High (Stoker and Ziska 2011). In both the North Rona and West Solan basins, Albian to Turonian rocks were deformed and eroded prior to Campanian sedimentation; the SW West Shetland Basin was also partially exposed (Fig. 4). Whereas some parts of the Rona High were accumulating sediment, a large tract of the high remained exposed. Collectively, these data suggest that the Orkney-Shetland hinterland, and extending into the Judd High-Outer Hebrides High region, might have remained as a largely subaerial region, part of a larger exposed Scottish landmass (e.g. Roberts et al. 1999).

The Faroe-Shetland Basin was the main focus of sedimentation at this time, and was characterised by the deposition of shallow-marine to basinal mudstone of the Kyrre Formation (Ritchie et al. 1996; Harker 2002; Stoker \& Ziska 2011) (Fig. 9d). The Kyrre Formation is also recorded from the West Shetland Basin, including the NE part of the basin which showed renewed fault activity at this time. In this basin, as well as on the adjacent Rona High, the Dab Limestone and Whiting Sandstone units (of the Kyrre Formation) reflect a mixed clastic-carbonate inner shelf facies. 
684 The predominance of the Faroe-Shetland Basin as the main depocentre is supported by the sediment accumulation rates for the Judd, Flett and Foula sub-basins, which range from 67$128 \mathrm{~m} \mathrm{Ma}^{-1}$ (Table 4). These rates contrast with an average basinal rate of $43.3 \mathrm{~m} \mathrm{Ma}^{-1}$ (Fig. 7). Whereas the average basinal rate is at its highest in the subsequent CampanianMaastrichtian interval, the peak rates for the Faroe-Shetland Basin are in the ConiacianSantonian (Table 4). The accumulation rates for the West Shetland Basin are also greater than in preceding intervals. On the basis of these data, it is suggested that a major phase of basin enlargement was instigated in the Coniacian with extension, deepening and high sediment accumulation rates evident from both the Faroe-Shetland and West Shetland basins (Fig. 2). By way of contrast, the SE Marginal Basins might have been largely exposed and part of the Orkney-Shetland hinterland. The formation and shaping of the MCU is one consequence of 695 this process.

Sedimentation throughout the region occurred largely within an aerobic, open marine environment (Ritchie et al. 1996; Harker 2002). However, despite the high rate of sediment accumulation, the provenance of the mainly fine-grained clastic material remains uncertain. An extensive hinterland to the south and east of the Faroe-Shetland Basin bordered by an inner shelf facies in the West Shetland Basin is depicted in Figure 9d, and adopts the view of Roberts et al. (1999) that a relatively large Scottish landmass existed at this time. This is consistent with the well data described above, and invokes a low relative sea level in this region. As this scenario contrasts with the generally high eustatic sea level that prevailed in the Late Cretaceous (Fig. 7), it strongly suggests that tectonic activity might have had a major bearing on the relatively low sea level assumed in this reconstruction. Major fault displacements along the Rona and Shetland Spine faults, including footwall uplift, have been described by Dean et al. (1999) and Goodchild et al. (1999), whereas the uplift and erosion of 
the SE Marginal Basins prior to the Campanian implies activity on the fault network bounding these basins, including the Judd Fault.

From the wider geographic area, shallow-marine rocks in the inner Hebridean region, which are comparable to the West Shetland Basin, contain sporadic conglomerate beds that are interpreted as evidence of tectonic activity throughout the Late Cretaceous (Mortimore et al. 2001; Emeleus \& Bell 2005). Farther west, Coniacian-Santonian conglomerates adjacent to the West Lewis High are cited as evidence of tectonic activity along the high, whereas marine mudstone continued to accumulate in the adjacent West Lewis and NE Rockall basins (Smith 2013). In the Kangerlussuaq Basin of SE Greenland, shallow-marine mudstone deposition prevailed during the Coniacian; however, a major unconformity marks the

Coniacian/Santonian boundary (Larsen et al. 1999a, 199b, 2005; Nøhr-Hansen 2012; Stoker et al. 2016). Significantly, perhaps, the uplift and erosion of this basin during the Santonian might have provided a separate north-westerly provenance for sediment input into the FaroeShetland Basin at this time (Nøhr-Hansen 2012). Evidence for a northerly provenance is also forthcoming from the Møre Basin where an increasingly expansive basinal drape of Coniacian-Santonian rocks developed (Brekke 2000), and it seems probable - from the available well evidence - that a marine connection to the Faroe-Shetland Basin was fully established at this time (Stoker and Ziska 2011).

Campanian-Maastrichtian. The Campanian-Maastrichtian interval is characterised by the widespread deposition of marine mudstones of the Kyrre and Jorsalfare formations across the Faroe-Shetland and SE Marginal basins, as well as many of the adjacent highs, including the total submergence of the Rona High (Fig. 9e). Sedimentation prevailed under aerobic, openmarine conditions (Ritchie et al. 1996; Harker 2002) and most basins, including the SE Marginal Basins, accumulated their thickest Cretaceous sections during this interval (Table 4). Sediment thicknesses in the West Shetland and East Solan basins exceed $1 \mathrm{~km}$, and in the 
Marginal Basins experienced dramatic increases in sediment accumulation rates, up to 142.5 $\mathrm{m} \mathrm{Ma}^{-1}$ in the South Solan Basin. Whereas the average basinal rate across the region is 65.9

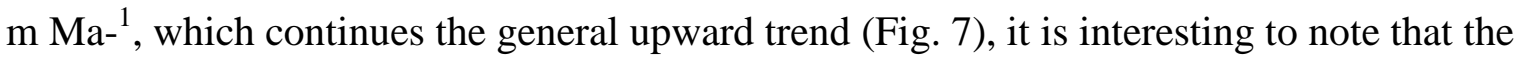
rates in the SE Marginal Basins and the West Shetland Basin largely outstrip those of the Faroe-Shetland Basin, where rates peaked in the Coniacian-Santonian interval (Table 4).

The increased sediment thicknesses and accumulation rates are consistent with the process of progressive basin enlargement during the Late Cretaceous (Dean et al. 1999). However, as was argued for the preceding Coniacian-Santonian interval, the combination of thick marine mudstones and high eustatic sea level does not necessarily imply total submergence of the Faroe-Shetland region in the Campanian-Maastrichtian. Intra-Campanian tectonic activity resulted in local basinal readjustments, such as within the NE West Shetland Basin where compression and folding created a late Campanian unconformity (Goodchild et al. 1999). The folding, uplift and erosion observed in the North Rona and West Solan basins might also have persisted into the Campanian, along with the continued exposure of the hinterland. The absence of Campanian-Maastrichtian rocks from the Westray and Corona highs (Fig. 5) might also reflect contemporary uplift of intra-basinal highs within the Faroe-Shetland Basin. Although latest Cretaceous/Early Paleocene uplift cannot be discounted, the sequence preserved on the Westray High implies intra-Campanian/Maastrichtian uplift and erosion. As a reflection of the uncertain extent of the Campanian-Maastrichtian hinterland, Figure 9e depicts a potential land/shelf transition zone. Whereas a Scottish landmass remains a viable sediment provenance, the possibility of a greater degree of hinterland submergence begs the question: where else could the vast quantity of sediment deposited in this interval have been sourced from? It is notable that throughout most of the Cretaceous development of the Faroe-

757 Shetland region, rifting was not accompanied by a significant thermal anomaly or an increase 
in heat flow (Dean et al. 1999). However, the early manifestations of breakup-related igneous activity, and their potential for thermally-induced uplift in areas immediately adjacent to the Faroe-Shetland region, were instigated in the Campanian-Maastrichtian. These include: 1) the Maastrichtian Anton Dohrn and Rosemary Bank volcanoes (seamounts) in the North Rockall Basin (Jones et al. 1974; Morton et al. 1995); and, 2) the Campanian and latest Maastrichtian instigation of the intrusion of a regional suite of basic igneous sills in extending from the Møre Basin to the NE Rockall Basin (Ritchie et al. 1999; Archer et al. 2005; Passey \& Hitchen 2011), which climaxed throughout the Faroe-Shetland-Rockall region in the Paleocene/Early Eocene. In the NE Rockall Basin, the intrusion of basic sills into Upper Cretaceous mudstones created a domal uplift, which might have had subaerial expression (Archer et al. 2005).

Elsewhere, much of the Campanian-Maastrichtian interval in the inner Hebridean region is marked by a hiatus (Mortimore et al. 2001). In contrast, the Kangerlussuaq Basin of SE Greenland was transgressed by shallow-marine mudstones (Larsen et al. 2005; Nøhr-Hansen 2012; Stoker et al. 2016), and there was widespread deposition of Campanian-Maastrichtian rocks in the Møre Basin (Brekke 2000). It is conceivable that the thick clastic sequences might be a reflection of a general exhumation of parts of the NE Atlantic rift system close to the line of incipient breakup (Doré et al. 1999), and which included the Faroe-Shetland region (Fig. 8). Ultimately, this may have been a factor in the formation of the BTU which reflects widespread uplift, re-emergence and erosion of most of the area flanking the SE margin of the Faroe-Shetland Basin in latest Maastrichtian/earliest Danian time (Fig. 4). In the inner Hebridean region, Mortimore et al. (2001) describe palaeovalleys cut at the end of the Cretaceous in response to faulting, uplift and erosion prior to the onset of Paleocene volcanism. In SE Greenland, the Maastrichtian/Danian boundary is marked by a major erosional unconformity that is attributed to an abrupt fall in relative sea level (Larsen et al. 
2005; Nøhr-Hansen, 2012). Similarly, on the eastern flank of the Orkney-Shetland hinterland, Maastrichtian and Danian units are separated by a break in sedimentation linked to a fall in relative sea level; this resulted in a seaward shift of the shoreline towards the eastern edge of the East Shetland High (Knox 2002).

Implications for the tectonic development of the Faroe-Shetland region

There is no doubt that the formation of the MCU represents a major shift in the tectonic development of the Faroe-Shetland region, marked especially by the expansion and increased subsidence of the Faroe-Shetland Basin, though extensional activity in all of the basins (i.e. West Shetland Basin and SE Marginal Basins) enabled them to accommodate the higher rates of influx of sediment into the area during the Coniacian-Maastrichtian (Figs 7 \& 9; Table 4). The K1/K2 megasequence arrangement described in this paper is the most visible expression of this regional change in basin geometry (Figs $2 \& 3$ ). This bipartite division provided the general basis for early ideas on tectonic development in the Faroe-Shetland region, some of which proposed 'Early’ Cretaceous rifting and 'Late’ Cretaceous thermal subsidence (e.g. Hitchen \& Ritchie 1987; Mudge \& Rashid 1987), whereas others (e.g. Duindam \& van Hoorn 1987; Booth et al. 1993; Knott et al. 1993) favoured renewed rifting during the 'Late' Cretaceous (post-Turonian/Coniacian). The latter viewpoint appears to represent the more recent general consensus (e.g. Dean et al. 1999; Doré et al. 1999; Grant et al. 1999; Goodchild et al. 1999; Lamers \& Carmichael 1999; Roberts et al. 1999; Larsen et al. 2010), and is clearly supported by this study.

Whereas the megasequence architecture expresses the large-scale sedimentary response to tectonic development, it does not detail the underlying processes responsible for the change in basin evolution. Instead, this detail is provided by the subdivision of the megasequences into higher-resolution second- and third-order depositional packages (Fig. 7), which reveals a 
more complex picture of basin development. The palaeogeographical depiction of these higher-order sequences (Fig. 9) provides a clearer appreciation of which basins were active, and when (summarised in Table 5). In common with various authors, especially Dean et al. (1999), it is clear that subsidence and uplift (including contractional deformation) varied both temporally and spatially across the Faroe-Shetland region. This would explain the variety of published rift ages described above for different basins across the area. The pattern of coeval extension and compression is consistent with a regional model of oblique-slip associated with transtension and/or transpression as proposed by Roberts et al. (1999). Although the detail clearly remains to be worked out, the palaeoegeographical maps imply a process of progressive basin enlargement and connectivity throughout the Cretaceous; this might reflect a transition from a non-interacting fault array in the initial stages of Early Cretaceous rifting to a fully connected fault system accompanied by accelerated subsidence in the ConiacianMaastrictian (Dean et al. 1999; Larsen et al. 2010).

From a wider perspective, the Faroe-Shetland region is part of the NE Atlantic Rift Zone (Fig. 8). Given the orientation of the Rift Zone relative to the developing North Atlantic spreading centre as well as the Alpine collisional zone, it would not be surprising that the Faroe-Shetland region developed as a zone of oblique-slip motion. In such a scenario, deformation generated by intraplate push-pull stresses, superimposed upon a structural framework dominated by NE- and NW-trending faults, would be accommodated by strikeslip displacements and pull-apart structures in some areas, and penecontemporaneous uplift and erosion in others; a pattern of basin development that seems compatible with the FaroeShetland region. Against this general model of background intraplate stress, inspection of Figure 7 might invite speculation concerning broad correlation between the timing of plate boundary forces on the margins of, and regional-scale sources of stress within the Laurasian 
continent, and basin development in the Faroe-Shetland region. Several key points to note are:

- The BCU might correlate with the Late Cimmerian event in the North Sea. The Late Cimmerian event and corresponding unconformity marks a change in the regional

- The Austrian Orogeny is linked to widespread compressional deformation in the North Sea (Oakman \& Partington 1998). This event extended into the late AlbianCenomanian and coincides with indicators of widespread uplift and erosion recorded across the Faroe-Shetland region; an area incorporating the SE Marginal Basins, the NE West Shetland Basin, the Rona High, and the northern Westray High.

- The time gap bracketed by the MCU in several of the SE Marginal Basins coincides with a prolonged phase of hinterland (NW Scotland) uplift (Holford et al. 2010) (Figs 6 \& 7). In the North Sea, the Cenomanian 'late’ Austrian compressional deformation was succeeded by a compressive pulse in the early to mid-Turonian, which might 

with significant contractional deformation in the Faroe-Shetland region (Fig. 7). Further compressive pulses in the North Sea in the early Campanian and around the central part of the rift zone (Fig. 8). According to Roberts et al. (1999), the NE Atlantic Rift Zone developed from linkage between southward-propagating (from the Arctic) and northward-propagating (from the North Atlantic) rift tips. These rift tips overlapped in the SE Greenland-NW British region, including the Faroe-Shetland region (Doré et al. 1999); thus, this region occupies a critical position in terms of understanding the nature and timing of 
linkage. Many previous palaeoegeographical reconstructions have considered that the Faroe-

Shetland region was part of a 'through-going' linked rift system and a substantial marine seaway that extended from the South Rockall Basin to the Vøring Basin since at least the Jurassic (e.g. Ziegler 1988; Cope et al. 1992; Doré 1992; Knott et al. 1993; Torsvik et al. 2002; Coward et al. 2003; McKie \& Williams 2009; Pharaoh et al. 2010) (Fig. 8). However, the Cretaceous tectonostratigraphic history detailed in this study directly challenges the viability of such putative reconstructions. The limitation on data, both structural and stratigraphical, from the western side of the Faroe-Shetland region is readily acknowledged in this study (Fig. 9), and is due to a lack of information from the Faroese sector. Nevertheless, there is enough information on basin development presented in this paper to suggest that the Faroe-Shetland Basin was not fully developed until the Late Cretaceous. This is consistent with a recent appraisal of the Permian to Cretaceous development of the entire NE Atlantic Rift Zone, which showed that it was not until the Cretaceous that a substantive rift system linking the Arctic and NE Atlantic regions across the SE Greenland-NW British region was established (Stoker et al. 2016). Significantly, perhaps, in those basins that would have been located in areas conjugate to the Faroe-Shetland region during the Mesozoic, i.e. the Kangerlussuaq and Ammassalik basins of SE Greenland (Fig. 8), as well as the adjacent

Cretaceous have thus far been recovered.

\section{Conclusions}

900

An appraisal of the Cretaceous succession has shown that the stratigraphical framework is characterised by depositional packages that record the sedimentary response at various levels to the process of rifting in the Faroe-Shetland region. At a first-order level, the unconformitybounded K1 and K2 megasequences represent a clear response to a major change in basin development; from an initial phase of rift initiation and growth (K1) in the Early and early 
Late Cretaceous, to a phase where the key controlling faults became more fully connected resulting in general basin enlargement and increased subsidence (K2) during the Late

907

Cretaceous. This regional change in basin evolution is marked by the MCU, which is a regional unconformity that separates Cenomanian/Turonian and older Cretaceous strata from Senonian-Maastrichtian rocks. However, the preserved rock record indicates that basin development was not a simple two-stage process, and was punctuated by intervals of uplift, erosion and contractional deformation. To fully understand the process of basin development it was necessary to consider the stratigraphical framework in terms of second- to third-order depositional sequences or 'sediment pulses'. By focusing specifically on the spatial and temporal distribution of the preserved late Berriasian-Barremian, Aptian-Albian, Cenomanian-Turonian, Coniacian-Santonian, and Campanian-Maastrichtian rocks it has been possible to identify the large-scale pattern of sedimentation and basin development throughout the region. In particular:

- Within the K1 megasequence, rift initiation in the late Berriasian-Barremian was switched to the Faroe-Shetland Basin in the Aptian-Albian, and further intensified in the Cenomanian-Turonian. Sedimentation persisted in the West Shetland Basin and SE Marginal Basins, though this was commonly interrupted by localised uplift and erosion of the sediments. A steady rise in the average basinal sediment accumulation rate reflects the overall intensification of rifting and increasing connectivity between basins across the region, though widespread uplift, erosion and contractional deformation in the late Albian-Turonian interval suggests that basins were not fully connected. The preponderance of paralic to shallow-marine clastic and carbonate sediments, including sporadically distributed coarse clastic facies, associated with the 
Cromer Knoll and Chalk groups - that constitute the bulk of the K1 megasequence is consistent with this tectonosedimentary setting.

- Within the K2 megasequence, there was a dramatic increase in sediment accumulation rates. Although the average basinal peak in accumulation rate occurred in the

In a wider context, the pattern of coeval extension and compression is consistent with regional strike-slip tectonics associated with transtension and/or transpression. From a consideration of the position of the Faroe-Shetland region generally within the Laurasian continent, and specifically as part of the developing NE Atlantic Rift Zone, it is likely that the 
954

955

956

957

intra-plate stress regime at this time was modulated by a combination of Atlantic spreading and the evolving Alpine Orogen on the southern and western margins of the plate, and the constraints imposed by Arctic Ocean spreading and orogenic activity on its northern plate margin. Key regional conclusions include:

- The BCU might be linked with the Late Cimmerian event in the North Sea, which marks the change in the regional stress field from E-W- to NW-SE-directed extension. It separates the Cretaceous rifting event from any previous rift activity in the Faroe-Shetland region.

- There is no evidence from the Faroe-Shetland region for a substantive through-going marine connection in the area between SE Greenland and NW Britain until the Late Cretaceous.

- Regional uplift associated with the BTU might be a wider expression of exhumation associated with the NE Atlantic Rift Zone linked to the developing thermal anomaly that accompanied Paleocene-earliest Eocene breakup off NW Britain

\section{Acknowledgements}

The author would like to thank Brian Bell and Emrys Phillips for their review of this paper, and to Alan Stevenson for his careful editing. This work could not have been undertaken without the support of the following oil companies who, together with the BGS and Jarðfeingi, formed the Faroe-Shetland Consortium (phases 1 \& 2) between 2008 and 2015: Centrica, Chevron, ConocoPhillips, Dana, DONG, E.ON, Faroe Petroleum, Nexen, Shell, Statoil and Total. The coastline used in this paper is courtesy of NOAA National Geophysical Data Center (GSHHS/World Vector Shoreline) (Wessel \& Smith 1996). The report contains public sector information licensed under the Open Government Licence v3.0. This consists of 
977 well locations based on information provided by DECC (the Department of Energy and 978 Climate Change), which is available online at https://www.gov.uk/oil-and-gas-offshore979 maps-and-gis-shapefiles. This paper is published with the permission of the Executive 980 Director of the British Geological Survey (NERC). 


\section{References}

ARCHER, S. G., BERGMAN, S. C., ILIFFE, J., MURPHY, C. M. \& THORNTON, M. 2005. Palaeogene igneous rocks reveal new insights into the geodynamic evolution and petroleum potential of the Rockall Trough, NE Atlantic Margin. Basin Research, 17, $171-201$.

BLYSTAD, P., BREKKE, H., FÆRSETH, R. B., LARSEN, B. T., SKOGSEID, J. \& TØRUDBAKKEN, B. 1995.Structural elements of the Norwegian continental shelf, Part II. The Norwegian Sea Region. Norwegian Petroleum Directorate Bulletin 8, 45pp.

BOOTH, J., SWIECICKI, T. \& WILCOCKSON, P. 1993. The tectono-stratigraphy of the Solan Basin, west of Shetland. In Parker, J. R. (ed) Petroleum Geology of Northwest Europe-Proceedings of the 4th Conference. The Geological Society, London, 987-998.

BREKKE, H. 2000. The tectonic evolution of the Norwegian Sea continental margin with emphasis on the Vøring and Møre basins. In Nøttvedt, A. et al. (eds) Dynamics of the Norwegian Margin. Geological Society, London, Special Publications 167, 327-378.

COPE, J. C. W. 2006. Upper Cretaceous palaeogeography of the British Isles and adjacent areas. Proceedings of the Geologists Association, 117, 129-143.

COPE, J. C. W., INGHAM, J. K. \& RAWSON, P. F. 1992. Atlas of Palaeogeography and Lithofacies. Geological Society, London, Memoir, 13.

COPESTAKE, P., SIMS, A., CRITTENDEN, S., HAMAR, G., INESON, J., ROSE, P. \& TRINGHAM, M. 2003. Lower Cretaceous. In: Evans, D., Graham, C., Armour, A., \& Bathurst, P. (eds and co-ordinators) The Millennium Atlas: petroleum geology of the central and northern North Sea. The Geological Society, London, 191-211. 
COWARD, M. P., DEWEY, J. F., HEMPTON, M. \& HOLROYD, J. 2003. Tectonic evolution. In Evans, D., Graham, C., Armour, A. \& Bathurst, P. (eds and co-ordinators) The Millennium Atlas: petroleum geology of the central and northern North Sea. The Geological Society, London, 17-33.

DEAN, K., MCLACHLAN, K. \& CHAMBERS, A. 1999. Rifting and the development of the Faeroe-Shetland Basin. In Fleet, A. J. \& Boldy, S. A. R. (ed) Petroleum Geology of Northwest Europe-Proceedings of the 5th Conference. The Geological Society, London, $533-544$.

DORÉ, A G. 1992. Synoptic palaeogeography of the Northeast Atlantic Seaway: late Permian to Cretaceous. In: Parnell, J (ed) Basins on the Atlantic Seaboard: Petroleum Geology, Sedimentology and Basin Evolution. Geological Society, London, Special Publications, 62, 421-446.

DORÉ, A. G., LUNDIN, E. R., JENSEN, L. N., BIRKELAND, Ø., ELIASSEN, P. E. \& FICHLER, C. 1999. Principal tectonic events in the evolution of the northwest European Atlantic margin. In Fleet, A. J. \& Boldy, S. A. R. (ed) Petroleum Geology of Northwest Europe-Proceedings of the 5th Conference. The Geological Society, London, 41-61.

DUINDAM, P. \& VAN HOORN, B. 1987. Structural evolution of the West Shetland continental margin. In Brooks, J. \& Glennie, K. (eds) Petroleum Geology of North West Europe-Proceedings of the $3^{\text {rd }}$ Conference. (London: Graham and Trotman), 765-773.

EMELEUS, C. H. \& BELL, B. R. 2005. British regional geology: the Palaeogene volcanic districts of Scotland (4th edition). (British Geological Survey, Nottingham.)

GOODCHILD, M. W., HENRY, K. L., HINKLEY, R. J. \& IMBUS, S. W. 1999. The Victory gas field, West of Shetland. In Fleet, A. J. \& Boldy, S. A. R. (eds) Petroleum 
Geology of Northwest Europe-Proceedings of the 5th Conference. The Geological Society, London, 713-724.

GRADSTEIN, F. M., OGG, J. G., SCHMITZ, M. D. \& OGG, G. 2012. The Geologic Time Scale 2012. Elsevier, Amsterdam.

GRANT, N., BOUMA, A. \& MCINTYRE, A. 1999. The Turonian play in the FaeroeShetland Basin. In Fleet, A. J. \& Boldy, S. A. R. (eds) Petroleum Geology of Northwest Europe, Proceedings of the 5th Conference. The Geological Society, London, 661-673.

GRANTZ, A., SCOTT, R. A., DRACHEV, S. S., MOORE, T. E. \& VALIN, Z. C. 2011. Sedimentary successions of the Arctic Region $\left(58-64^{\circ}\right.$ to $\left.90^{\circ} \mathrm{N}\right)$ that may be prospective for hydrocarbons. In: Spencer, A. M., Embry, A. F., Gautier, D. L., Stoupakova, A. V. \& Sørensen, K. (eds) Arctic Petroleum Geology. Geological Society, London, Memoirs, 35, $17-37$.

HANCOCK, J. M. \& RAWSON, P. F. 1992. Cretaceous. In Cope, J. C. W., Ingham, J. K. \& Rawson, P. F. (eds) Atlas of Palaeogeography and Lithofacies. Geological Society, London, Memoir 13, 131-138.

HASZELDINE, R. S., RITCHIE, J. D., \& HITCHEN. K. 1987. Seismic and well evidence for the early development of the Faroe-Shetland Basin. Scottish Journal of Geology, 23, 283-300.

HARKER, S. D. 2002. Cretaceous. In Trewin, N. (ed) The Geology of Scotland, (4 ${ }^{\text {th }}$ edition). The Geological Society, London, 351-360.

HITCHEN, K. \& RITCHIE, J. D. 1987. Geological review of the West Shetland area. In Brooks, J. \& Glennie, K. (eds) Petroleum Geology of North West Europe-Proceedings of the $3^{\text {rd }}$ Conference. (London: Graham and Trotman), 737-749. 
HOLFORD, S. P., GREEN, P. F., HILLIS, R. R., UNDERHILL, J. R., STOKER, M. S. \& DUDDY, I. R. 2010. Multiple post-Caledonian exhumation episodes across NW Scotland revealed by apatite fission-track analysis. Journal of the Geological Society, London, 176, 675-694.

HUBBARD, R.J., PAPE, T. \& ROBERTS, D.G. 1985. Depositional sequence mapping as a technique to establish tectonic and stratigraphic framework and evaluate hydrocarbon potential on a passive continental margin. In Berg, O.R. \& Woolverton, D.G. (eds) Seismic Stratigraphy II: An Integrated Approach. American Association of Petroleum Geologists Memoir 39, 79-91.

JOHNSON, H. \& LOTT, G. K. 1993. 2. Cretaceous of the Central and Northern North Sea. In: Knox, R. W. O’B. \& Cordey, W. G. (eds) Lithostratigraphic nomenclature of the UK North Sea. British Geological Survey, Nottingham.

JOHNSON, H., RICHARDS, P. C., LONG, D. \& GRAHAM, C. C. 1993. United Kingdom offshore regional report: the geology of the northern North Sea. (London: HMSO for the British Geological Survey, 110 pp.

JOHNSON, H., RITCHIE, J. D., HITCHEN, K., MCINROY, D. B., \& KIMBELL, G. S. 2005. Aspects of the Cenozoic deformational history of the northeast Faroe-Shetland Basin, Wyville-Thomson Ridge and Hatton Bank areas. In Doré, A. G. \& Vining, B. (eds) Petroleum Geology: NW Europe and Global Perspectives-Proceedings of the $6^{\text {th }}$ Conference. The Geological Society, London, 993-1007.

JONES, E. J. W., RAMSAY, A. T. S., PRESTON, N. J. \& SMITH, A. C. S. 1974. A Cretaceous guyot in the Rockall Trough. Nature, 251, 129-131.

KESER NEISH J. \& ZISKA, H. 2005. Structure of the Faroe Bank Channel, offshore Faroe Islands. In Doré, A. G. \& Vining, B. A. (eds) Petroleum Geology: North-West Europe 
and Global Perspectives-Proceedings of the $6^{\text {th }}$ Conference. The Geological Society, London, 873-885.

KNOTT, S. D., BURCHELL, M. T., JOLLEY, E. J. \& FRASER, A. J. 1993. Mesozoic to Cenozoic plate reconstructions of the North Atlantic and hydrocarbon plays of the Atlantic margins. In: Parker, J. R. (ed) Petroleum Geology of Northwest EuropeProceedings of the $4^{\text {th }}$ Conference. The Geological Society, London, 953-974.

KNOX, R. W. O’B. 2002. Tertiary sedimentation. In: Trewin, N. (ed) The Geology of Scotland, (4th edition). The Geological Society, London, 361-370.

LAMERS, E. \& CARMICHAEL, S. M. M. 1999. The Paleocene deepwater sandstone play West of Shetland. In Fleet, A. J. \& Boldy, S. A. R. (eds) Petroleum Geology of Northwest Europe: Proceedings of the $5^{\text {th }}$ Conference. The Geological Society, London, 645-659.

LARSEN, M., HAMBERG, L., OLAUSSEN, S., NØRGAARD-PEDERSEN, N. \& STEMMERIK, L. 1999a. Basin evolution in southern East Greenland: an outcrop analog for Cretaceous-Paleogene basins on the North Atlantic volcanic margins. American Association of Petroleum Geologists Bulletin, 83, 1236-1261.

LARSEN, M., HAMBERG, L., OLAUSSEN, S., PREUSS, T. \& STEMMERIK, L. 1999b. Sandstone wedges of the Cretaceous-Lower tertiary Kangerlussuaq Basin, east Greenland - outcrop analogues to the offshore Atlantic. In: Fleet, A. J. \& Boldy, S. A. R. (eds) Petroleum Geology of Northwest Europe: Proceedings of the $5^{\text {th }}$ Conference. The Geological Society, London, 337-348.

LARSEN, M., NØHR-HANSEN, H., WHITHAM, A. G. \& KELLY, S. R. A. 2005. Stratigraphy of the pre-basaltic sedimentary succession of the Kangerlussuaq Basin, 
Volcanic Basin of the North Atlantic. Final report for the Sindri Group, September 2005, Danmarks og Grønlands Geologiske Undersøgelse Rapport 2005/62, 1-41.

LARSEN, M., RASMUSSEN, T. \& HJELM, L. 2010. Cretaceous revisited: exploring the syn-rift play of the Faroe-Shetland Basin. In Vining, B. A. \& Pickering, S. C. (eds) Petroleum Geology: From Mature Basins to New Frontiers-Proceedings of the $7^{\text {th }}$ Petroleum Geology conference. The Geological Society, London, 953-962.

LUNDIN, E. R. \& DORÉ, A. G. 1997. A tectonic model for the Norwegian passive margin with implications for the NE Atlantic: Early Cretaceous to break-up. Journal of the Geological Society, London, 154, 545-550.

LUNDIN, E. R. \& DORÉ, A. G. 2005. NE Atlantic break-up: a re-examination of the Iceland mantle plume model and the Atlantic-Arctic linkage. In Doré, A. G. \& Vining, B. (eds) Petroleum Geology: North-West Europe and Global Perspectives-Proceedings of the 6th Petroleum Geology Conference. The Geological Society, London, 739-754.

MCCANN, T., SHANNON, P. M. \& MOORE, J. G. 1995. Fault styles in the Porcupine Basin, offshore Ireland: tectonic and sedimentary controls. In Croker, P. F. \& Shannon, P. M. (eds) The Petroleum Geology of Ireland's Offshore Basins. Geological Society, London, Special Publications, 93, 371-383.

MCKIE, T \& WILLIAMS, B. 2009. Triassic palaeogeography and fluvial dispersal systems across the northwest European Basins. Geological Journal, 44, 711-741.

MEADOWS, N. S., MACCHI, L., CUBITT, J. M. \& JOHNSON, B. 1987. Sedimentology and reservoir potential in the west of Shetland, UK, exploration area. In Brooks, J. \& Glennie, K. (eds) Petroleum Geology of North West Europe-Proceedings of the $3^{\text {rd }}$ Conference. (London: Graham and Trotman), 723-736. 
MORTIMORE, R., WOOD, C. GALLOIS, R. 2001. British Upper Cretaceous stratigraphy. Geological Conservation Review Series, 23. (Peterborough: Joint Nature Conservation Committee.)

MORTON, A. C., HITCHEN, K., RITCHIE, J. D., HINE, N. M., WHITEHOUSE, M. \& CARTER, S. G. 1995. Late Cretaceous basalts from Rosemary Bank, northern Rockall Trough. Journal of the Geological Society of London, 152, 947-952.

MOY, D. J. \& IMBER, J. 2009. A critical analysis of the structure and tectonic significance of rift-oblique lineaments ('transfer zones') in the Mesozoic-Cenozoic succession of the Faroe-Shetland Basin, NE Atlantic margin. Journal of the Geological Society, London, $166,831-844$.

MUDGE, D. C. \& RASHID, B. 1987. The geology of the Faeroe Basin area. In Brooks, J. \& Glennie, K. (eds) Petroleum Geology of North West Europe-Proceedings of the $3^{\text {rd }}$ Conference. (London: Graham and Trotman), 751-763.

MUSGROVE, F. W. \& MITCHENER, B. 1996. Analysis of the pre-Tertiary history of the Rockall Trough. Petroleum Geoscience, 2, 353-360.

NØHR-HANSEN, H. 2012. Palynostratigraphy of the Cretaceous-lower Palaeogene sedimentary succession in the Kangerlussuaq Basin, southern East Greenland. Review of Palaeobotany and Palynology, 178, 59-90.

OAKMAN, C. D. \& PARTINGTON, M. A. 1998. Cretaceous. In Glennie, K. W. (ed) Petroleum Geology of the North Sea: Basic Concepts and Recent Advances. (Blackwell Science: Oxford), 295-349.

ÓLAVSDÓTTIR, J., ANDERSEN, M. S., \& BOLDREEL, L. O. 2013. Seismic stratigraphic analysis of the Cenozoic sediments in the NW Faroe Shetland Basin - implications for 
inherited structural control of sediment distribution. Marine and Petroleum Geology, 46, $19-35$.

PASSEY, S. R. \& HITCHEN, K. 2011. Cenozoic (igneous). In Ritchie, J. D., Ziska, H., Johnson, H. \& Evans, D. (eds). Geology of the Faroe-Shetland Basin and adjacent areas. British Geological Survey Research Report, RR/11/01, Jarðfeingi Research Report, RR/11/01, 209-228.

PHARAOH, T. C., DUSAR, M., GELUK, M. C., KOCKEL, F., KRAWCZYK, C. M., KRYZWIEC, P., SCHECK-WENDEROTH, M., THYBO, H., VEJBÆK, O. V. \& VAN WEES, J. D. 2010. Tectonic Evolution. In: Doornenbal, J. C. \& Stevenson, A. G. (eds) Petroleum Geological Atlas of the Southern Permian Basin Area. EAGE Publications b.v., Houten, 25-57.

RAUM,T., MJELDE, R., BERGE, A. M., PAULSEN, J. T., DIGRANES, P., SHIMAMURA, H., SHIOBARA, H., KODAIRA, S., LARSEN, V. B., FREDSTED, R., HARRISOA, D. J., \& JOHNSON, M. 2005. Sub-basalt structures east of the Faroe Islands revealed from wide-angle seismic and gravity data. Petroleum Geoscience, 11, 291-308.

RITCHIE, J. D., GATLIFF, R. W. \& RIDING, J. B. 1996. Stratigraphic Nomenclature of the UK North West Margin. 1. Pre-Tertiary Lithostratigraphy. British Geological Survey, Nottingham.

RITCHIE, J. D., GATLIFF, R. W. \& RICHARDS, P. C. 1999. Early Tertiary magmatism in the offshore NW UK margin and surrounds. In Fleet, A. J. \& Boldy, S. A. R. (eds) Petroleum Geology of Northwest Europe-Proceedings of the $5^{\text {th }}$ Conference. The Geological Society, London, 573-584. 
RITCHIE, J. D., JOHNSON, H. QUINN, M. F. \& GATLIFF, R. W. 2008. Cenozoic compressional deformation within the Faroe-Shetland Basin and adjacent areas. In: Johnson, H., Doré, A. G., Holdsworth, R. E., Gatliff, R. W., Lundin, E. R. \& Ritchie, J. D. (editors) The Nature and Origin of Compression in Passive Margins. The Geological Society, London, Special Publications, 306, 121-136.

RITCHIE, J. D., ZISKA, H., KIMBELL, G., QUINN, M. F. \& CHADWICK, A. 2011. Structure. In Ritchie, J. D., Ziska, H., Johnson, H. \& Evans, D. (eds) Geology of the Faroe-Shetland Basin and adjacent areas. British Geological Survey Research Report, RR/11/01; Jarðfeingi Research report, RR/11/01, 9-70.

RITCHIE, J. D., JOHNSON, H., KIMBELL, G. S. \& QUINN, M. F. 2013. Structure. In: Hitchen, K., Johnson, H. \& Gatliff, R. W. (eds) Geology of the Rockall Basin and adjacent areas. British Geological Survey Research Report, RR/12/03, 10-46.

ROBERTS, D. G., THOMPSON, M., MITCHENER, B., HOSSACK, J., CARMICHAEL, S. \& BJØRNSETH, H-M. 1999. Palaeozoic to Tertiary rift and basin dynamics: midNorway to the Bay of Biscay - a new context for hydrocarbon prospectivity in the deep water frontier. In Fleet, A. J. \& Boldy, S. A. R. (eds) Petroleum Geology of Northwest Europe-Proceedings of the $5^{\text {th }}$ Conference. The Geological Society, London, 7-40.

RUMPH, B., REAVES, C. M., ORANGE, V. G. \& ROBINSON, D. L. 1993. Structuring and transfer zones in the Faeroe Basin in a regional context. In Parker, J. R. (ed) Petroleum Geology of Northwest Europe-Proceedings of the 4th Conference. The Geological Society, London, 999-1009.

SIBUET, J-J, SRIVASTAVA, S P, and SPAKMAN, W. 2004. Pyrenean orogeny and plate kinematics. Journal of Geophysical Research, 109, B08104, doi:10.1029/2003JB002514. 
SMALLWOOD, J. R., TOWNS, M. J., \& WHITE, R. S. 2001. The structure of the FaroeShetland Trough from integrated deep seismic and potential field modelling. Journal of the Geological Society, London, 158, 409-412.

SMITH, K. 2013. Cretaceous. In: Hitchen, K., Johnson, H. \& Gatliff, R. W. (eds) Geology of the Rockall Basin and adjacent areas. British Geological Survey Research Report, $\mathrm{RR} / 12 / 03,71-80$.

STOKER, M. S. \& ZISKA, H. 2011. Cretaceous. In Ritchie, J. D., Ziska, H., Johnson, H. \& Evans, D. (eds) Geology of the Faroe-Shetland Basin and adjacent areas. British Geological Survey Research Report, RR/11/01; Jarðfeingi Research report, RR/11/01, $123-150$.

STOKER, M. S., HITCHEN, K. \& GRAHAM, C. C. 1993. United Kingdom offshore regional report: the geology of the Hebrides and West Shetland shelves and adjacent deep-water areas. (London: HMSO for the British Geological Survey), 149 pp.

STOKER, M. S., PRAEG, D., SHANNON, P. M., HJELSTUEN, B. O., LABERG, J. S., VAN WEERING, T. C. E., SEJRUP, H. P. \& EVANS, D. 2005. Neogene evolution of the Atlantic continental margin of NW Europe (Lofoten Islands to SW Ireland): anything but passive. In Doré, A. G. \& Vining, B. (eds) Petroleum Geology: North-West Europe and Global Perspectives-Proceedings of the 6th Petroleum Geology Conference. The Geological Society, London, 1057-1076.

STOKER, M. S., HOLFORD, S. P., HILLIS, R. R., GREEN, P. F. \& DUDDY, I. R. 2010. Cenozoic post-rift sedimentation off northwest Britain: Recording the detritus of episodic uplift on a passive continental margin. Geology, 38, 595-598. 
STOKER, M. S., LESLIE, A. B., \& SMITH, K. 2013. A record of Eocene (Stronsay Group) sedimentation in BGS borehole 99/3, offshore NW Britain: Implications for early postbreakup development of the Faroe-Shetland Basin. Scottish Journal of Geology, 49, 133148.

STOKER, M. S., STEWART, M. A., SHANNON, P. M., BJERAGER, M., NIELSEN, T., BLISCHKE, A., HJELSTUEN, B. O., GAINA, C., MCDERMOTT, K. \& ÓLAVSDÓTTIR, J. 2016. An overview of the Upper Paleozoic-Mesozoic stratigraphy of the NE Atlantic region. In Peron-Pinvidic, G., Hopper, J., Stoker, M. S., Gaina, C., Doornenbal, H., Funck, T. \& Árting, U. (eds) The North-East Atlantic region: A Reappraisal of Crustal Structure, Tectono-stratigraphy and Magmatic Evolution. Geological Society, London, Special Publications 447, In press.

TORSVIK, T H, CARLOS, D, MOSAR, M, COCKS, L R M \& MALME, T. 2002. Global reconstructions and North Atlantic paleogeography 440 Ma to Recent. In: Eide, E A (coord) BATLAS - Mid Norway plate reconstruction atlas with global and Atlantic perspectives. Geological Survey of Norway, 18-39

TURNER, J. D. \& SCRUTTON, R. A. 1993. Subsidence patterns in western margin basins: evidence from the Faeroe-Shetland Basin. In Parker, J.R. (ed) Petroleum Geology of Northwest Europe-Proceedings of the $4^{\text {th }}$ Conference. (London: The Geological Society), 975-983.

VESTRALEN, I., HARTLEY, A. J. \& HURST, A. 1995. The sedimentology of the Rona Sandstone (Upper Jurassic), West of Shetlands, UK. In: Hartley, A. J. \& Prosser, D. J. (eds) Characterisation of Deep-Marine Clastic Systems. Geological Society, London, Special Publications, 94, 155-176. 
1231

1232

1233

1234

1235

WESSEL, P \& SMITH, W H F. 1996. A Global Self-consistent, Hierarchical, High-

Resolution Shoreline Database. Journal of Geophysical Research, 101, 8741-8743.

ZIEGLER, P. A. 1988. Evolution of the Arctic-North Atlantic and the Western Tethys.

American Association of Petroleum Geologists, Tulsa, Memoir 43. 
FIGURES

1238

1. Map showing location and structural setting of study area, general distribution of the Cretaceous succession, positions of commercial wells used in this study, and UK and Faroese quadrant numbers. Structural elements of the Faroe-Shetland area based on Lamers \& Carmichael (1999), Larsen et al. (2010) and Ritchie et al. (2011), with information from peripheral areas from Johnson et al. (1993) and Ritchie et al. (2013). Inset shows regional setting of Faroe-Shetland Basin. Abbreviations: COB, continent-ocean boundary; ERH, East Rona High; FB, Fetlar Basin; FFZ, Faroes Fracture Zone; GGF, Great Glen Fault; JF, Judd Fault; MG, Magnus Basin; MT, Moine Thrust; NLB, North Lewis Basin; NRSSH, Nun Rock-Sule Skerry High; RF, Rona Fault; RHc, Rona High central; RHne, Rona High north-east; RHsw, Rona High south-west; RHsw/c, Rona High south-west/central; SB, Sandwick Basin; SSF, Shetland Spine Fault; WBF, Walls Boundary Fault; WF, Westray Fault; WRH, West Rona High.

2. Geoseismic profiles showing the generalised structural and stratigraphical framework of the Faroe-Shetland region, and the delineation of the Cretaceous succession into two regionally mappable units (K1 and K2). Line drawings modified after Stoker et al. (1993) and Lamers \& Carmichael (1999) (profiles a and c), and Ritchie et al. (2011) (profile b). Inset map shows location of profiles in Figs 2 \& 3 relative to simplified structural framework of Faroe-Shetland Basin, West Shetland Basin and SE Marginal Basins. Abbreviations: BCU, Base Cretaceous Unconformity; BTU, Base Tertiary Unconformity; COB, Continent-Ocean Boundary; ESB, East Solan Basin; MCU, ‘Mid’ Cretaceous Unconformity; NRB, North Rona Basin; PB, Papa 

Spine Fault; WSB, West Solan Basin; WShB, West Shetland Basin.

1262

1263

1264

1265

3. Geoseismic profiles showing the structural and stratigraphical disposition of the Cretaceous rocks in the West Solan and North Rona basins, and the delineation of the Cretaceous succession into two regionally mappable units (K1 and K2). Line drawings based on information supplied by Chevron North Sea Limited. Abbreviations: BCU, Base Cretaceous Unconformity; BTU, Base Tertiary Unconformity; MCU, ‘Mid’ Cretaceous Unconformity. Profiles located in Fig. 2.

4. Cretaceous stratigraphy of the SE Marginal Basins, West Shetland Basin and the Rona High, indicating stratigraphical range, thickness and sedimentary environment of the preserved rocks, and age of the underlying and oldest overlying strata, based on data derived from Stoker \& Ziska (2011). The approximate stratigraphical position of the regionally-significant Base Cretaceous Unconformity (BCU) and 'Mid' Cretaceous Unconformity (MCU) is also shown; the top of the succession is bounded by the Base Tertiary Unconformity (BTU). See Table 1 for well database. Lithostratigraphical nomenclature after Ritchie et al. (1996); timescale is based on Gradstein et al. (2012).

5. Cretaceous stratigraphy of the Faroe-Shetland Basin indicating stratigraphical range, drilled thickness and sedimentary environment of the preserved rocks, and age of the underlying and oldest overlying strata, based on data derived from Stoker \& Ziska (2011). The approximate stratigraphical position of the regionally-significant 'Mid' Cretaceous Unconformity (MCU) is also shown; the top and base of the succession is bounded by the Base Tertiary Unconformity (BTU) and Base Cretaceous Unconformity (BCU), respectively. See Table 1 for well database. 
Lithostratigraphical nomenclature after Ritchie et al. (1996); timescale is based on Gradstein et al. (2012).

6. Summary of Cretaceous stratigraphical framework for the Faroe-Shetland region, combining lithostratigraphical and seismic-stratigraphical data. Abbreviations: BB, Black Band; BCU, Base Cretaceous Unconformity; BTU, Base Tertiary Unconformity; DLU, Dab Limestone Unit; HSU, Haddock Sandstone Unit; HUM, Humber Group; KCF, Kimmeridge Clay Formation; MCU, 'Mid’ Cretaceous Unconformity; PSU, Phoebe Sandstone Unit; WSU, Whiting Sandstone Unit. Lithostratigraphical nomenclature after Ritchie et al. (1996); timescale is based on Gradstein et al. (2012).

7. Cretaceous tectonostratigraphical framework for the Faroe-Shetland region. The compilation of the Stratigraphy, Sedimentation and Faroe-Shetland Tectonics is based on this study. For the Sediment Pulses, the circled letters (a) to (e) relate to the palaeogeographic maps illustrated in Figure 9. Additional information is derived from the following sources-Regional Tectonics: NW Scotland exhumation - Holford et al. (2010); Orogenic collision forces and regional extension vectors - Oakman \& Partington (1998), Doré et al. (1999); Rotation of Greenland - Ziegler (1988); Intraplate volcanism - Ritchie et al. (1999), Passey \& Hitchen (2011); Spreading history - Doré et al. (1999), Lundin \& Doré (2005). Sea level: Gradstein et al. (2012). Abbreviations: BCU, Base Cretaceous Unconformity; BTU, Base Tertiary Unconformity; MCU, ‘Mid’ Cretaceous Unconformity. Timescale is based on Gradstein et al. (2012)

8. Location and gross tectonic setting of the Faroe-Shetland region in the context of the 'Mid' Cretaceous reconstruction of the northern part of the Pangaean plate (i.e. 
Laurasia), but including indications of the Late Cretaceous rotation of Greenland and Eurekan orogenic zone. The configuration of Laurasia is based on 'Mid' Cretaceous reconstructions of Ziegler (1988) and Doré et al. (1999), and also includes information derived from Ritchie et al. (2011, 2013) and Stoker et al. (2016). Abbreviations: AM, Ammassalik Basin; BK, Blosseville Kyst; ER, Erris Basin; FS, Faroe-Shetland Basin; HE, Hebridean region; HT, Hatton Basin; KG, Kangerlussuaq Basin; MØ, Møre Basin; NEG, NE Greenland; NR, North Rockall Basin; PO, Porcupine Basin; SR, South Rockall Basin; VK, Viking Graben; VØ, Vøring Basin.

9. Series of schematic palaeoegeographical maps showing the inferred spatial and temporal development of the Faroe-Shetland region during Cretaceous times: (a) late Berriasian-Barremian; (b) Aptian-Albian; (c) Cenomanian-Turonian; (d) ConiacianSantonian; (e) Campanian-Maastrichtian. Abbreviations: CH, Corona High; EH, Erlend High; ELsB, Erlend sub-Basin; ESB, East Solan Basin; ESH, East Shetland High; FH, Flett High; FLsB, Flett sub-Basin; FsB, Foula sub-Basin; JF, Judd Fault; JH, Judd High; JsB, Judd sub-Basin; MB, Muckle Basin; NERB, NE Rockall Basin; NRB, North Rona Basin; NSH, North Shetland High; OHH, Outer Hebrides High; OSH, Orkney-Shetland High; PB, Papa Basin; RF, Rona Fault; RH, Rona High; SBH, Solan Bank High; SSB, South Solan Basin; SSF, Shetland Spine Fault; UB, Unst Basin; WF, Westray Fault; WH, Westray High; WSB, West Solan Basin; WSH, West Shetland High; WSHB, West Shetland Basin; YsB, Yell sub-Basin.

\section{TABLES}

1. Commercial wells used in this study 
2. Summary of lithology and depositional environment of the Cretaceous lithostratigraphical groups and formations. Information derived from Ritchie et al. (1996) and Harker (2002)

3. Regional setting and gross stratigraphical characteristics of the South-East Marginal Basins (North Rona, West Solan, East Solan and South Solan basins), the West Shetland Basin, and the sub-basins (Judd, Flett, Foula, Erlend and Yell) that form part of the Faroe-Shetland Basin, based on data used in this study as well as published information as follows: ${ }^{1}$ Ritchie et al. (2011); ${ }^{2}$ Moy \& Imber (2009); ${ }^{3}$ Booth et al. (1993); ${ }^{4}$ Lamers \& Carmichael (1999); ${ }^{5}$ Dean et al. (1999); ${ }^{6}$ Goodchild et al. (1999); ${ }^{7}$ Grant et al. (1999); ${ }^{8}$ Larsen et al. (2010).

4. Maximum-drilled sediment thicknesses recorded from basinal wells listed in Table 1 and the corresponding sediment accumulation rates for the following stages: LB-B, Late Berriasian-Barremian; A-A, Aptian-Albian; C-T, Cenomanian-Turonian; C-S, Coniacian-Santonian; C-M, Campanian-Maastrichtian. The sediment accumulation rate should be regarded as a minimum as it is based on drilled sections only and undecompacted rock thicknesses.

5. Summary of basin development 
Fig. 1

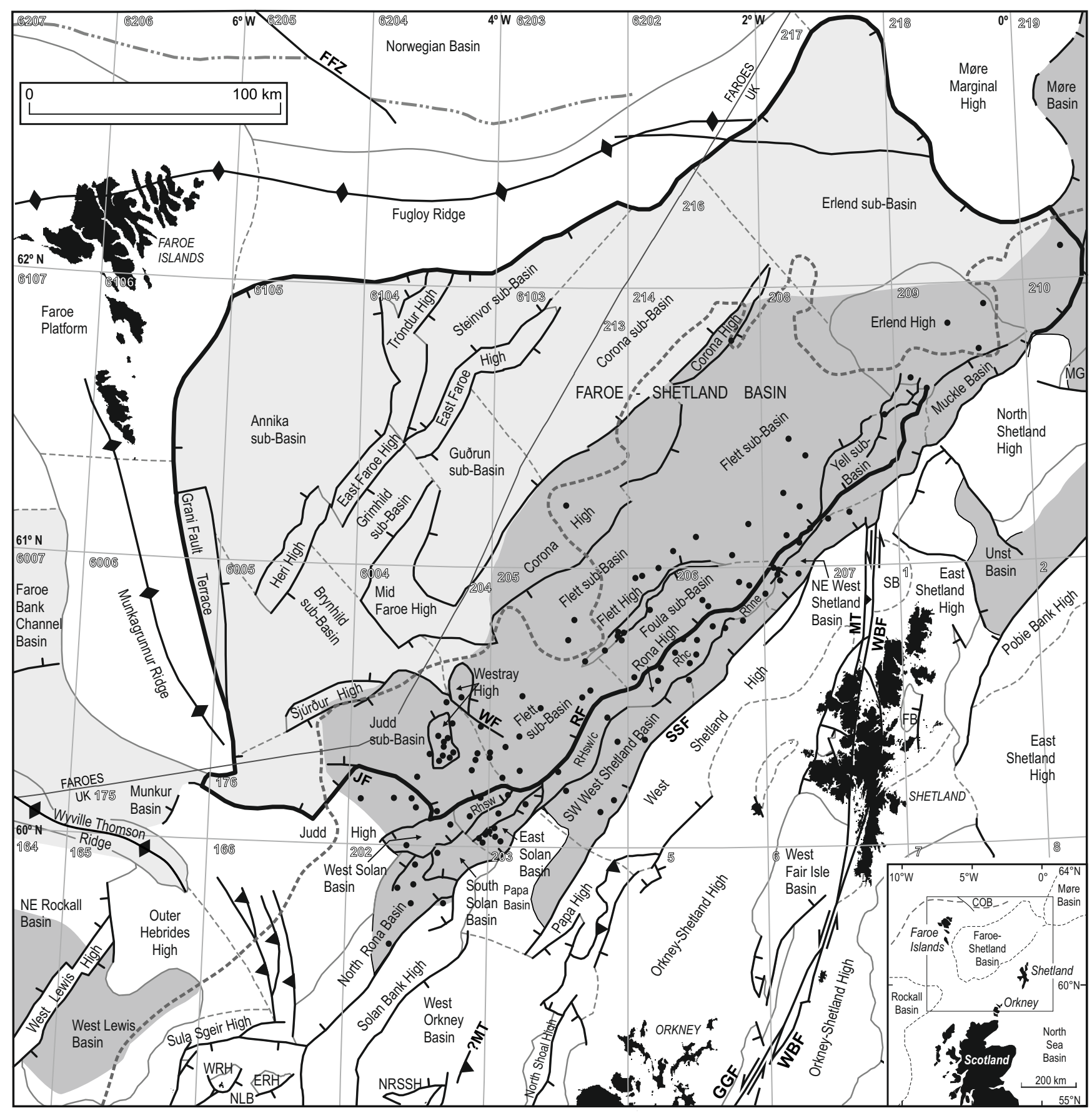

Key to main map
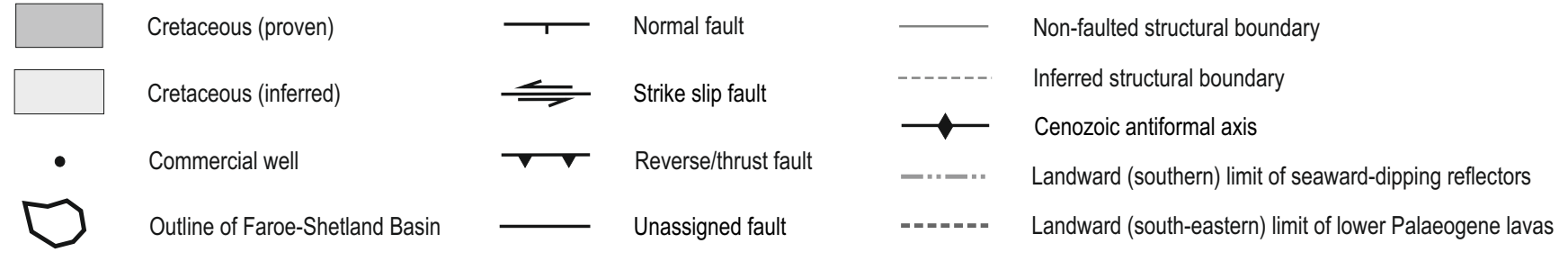
Fig. 2

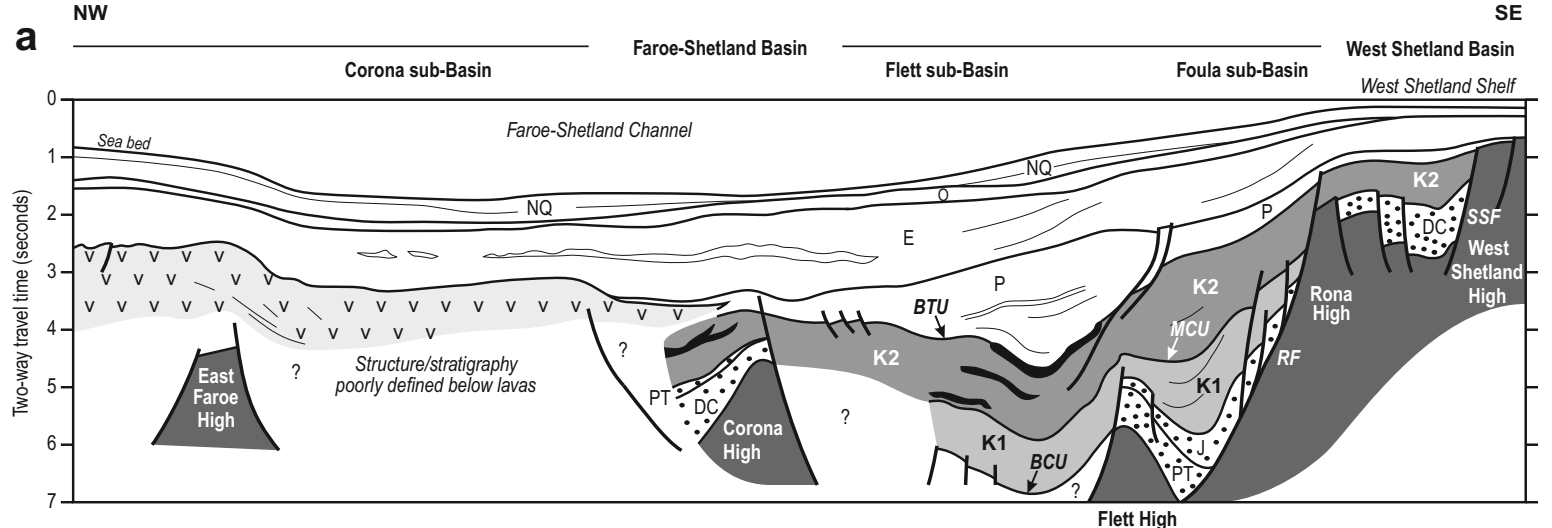

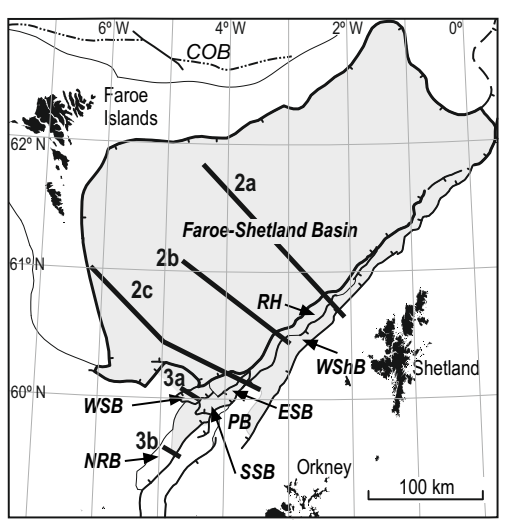

Key to inset map

Total inferred distribution of Cretaceous rocks in Faroe-Shetland Basin, West
Shetland Basin and SE Marginal Basins

C $\stackrel{\text { NW }}{\longrightarrow}$ Faroe-Shetland Basin

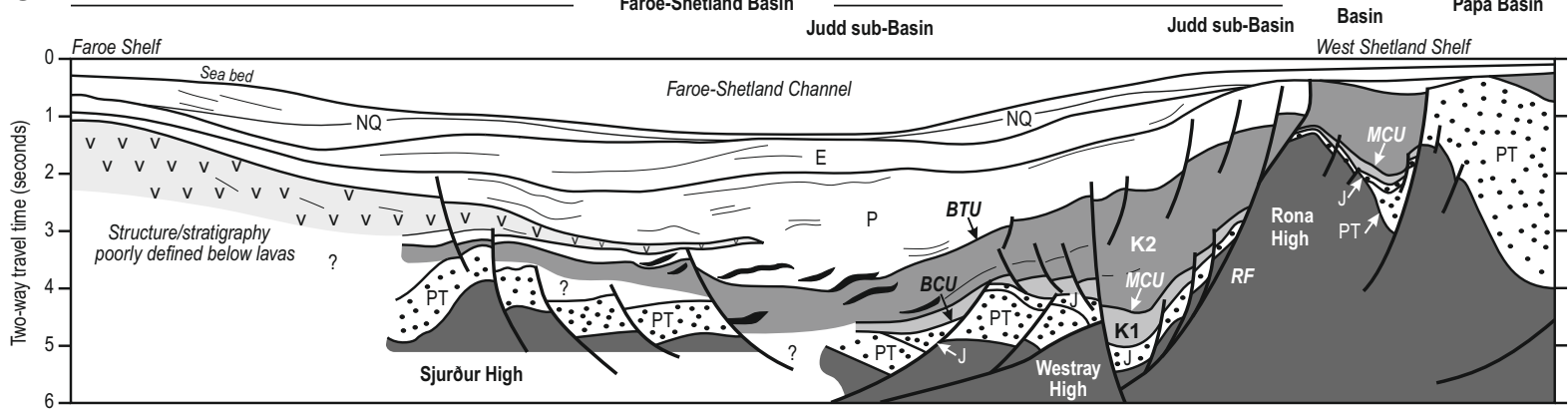

Key to geoseismic sections

7 Cenozoic. Abbreviations: NQ, Neogene-Quaternary; $\mathrm{O}$, Oligocene; E, Eocene; P, Paleocene

\begin{tabular}{|l|l|l}
$\vee \vee \vee v$ & $\begin{array}{l}\text { Lower Palaeogene lavas } \\
\text { and volcaniclastic rocks }\end{array}$ & $\begin{array}{l}\text { Lower Palaeogene } \\
\text { sills }\end{array}$
\end{tabular}

K2 Upper Cretaceous predominantly post-Turonian

K1 Lower to 'Mid' Cretaceous, including Cenomanian/Turonian
25 kilometres

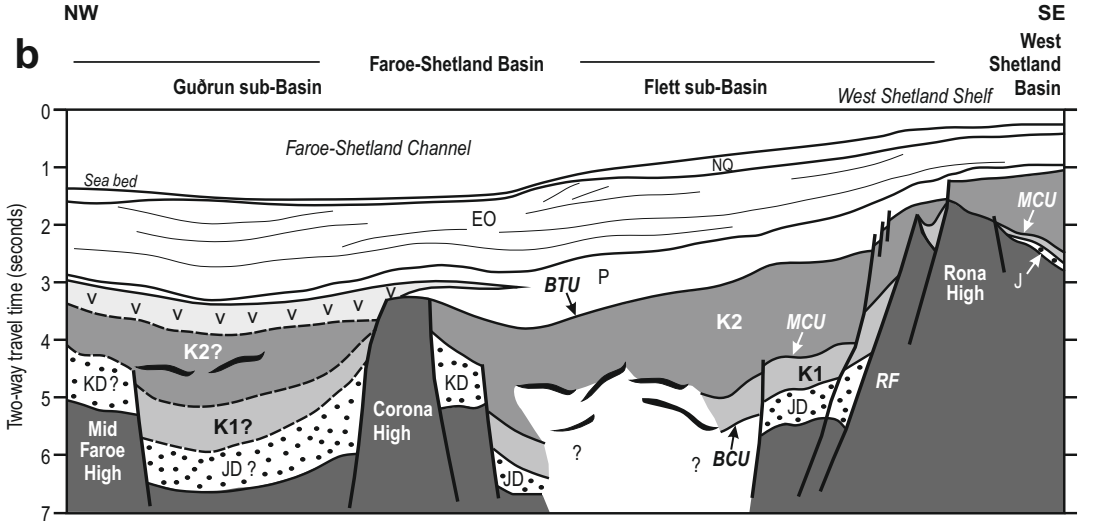

25 kilometres 
Fig. 3

a

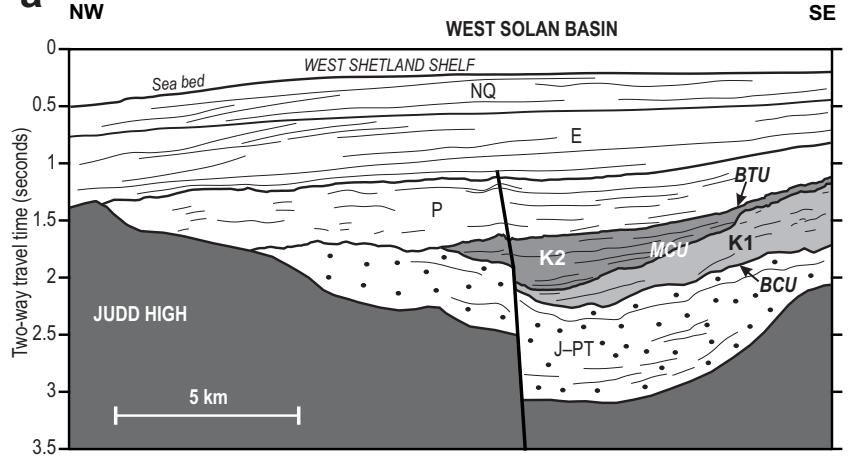

b

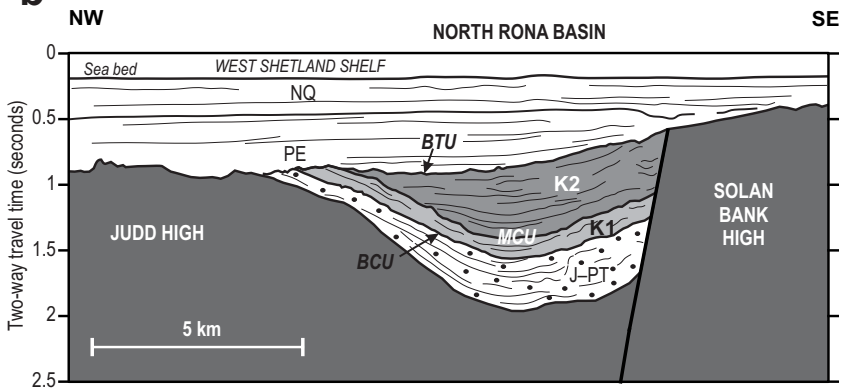

Key

Cenozoic. Abbreviations: NQ, Neogene-Quaternary; E, Eocene; P, Paleocene; $\mathrm{PE}$, Paleocene-Eocene

$\mathrm{K} 2$

Upper Cretaceous, predominantly post-Turonian

K1 Lower to 'Mid' Cretaceous, including Cenomanian/Turonian

$\because \because \because \quad$ Mesozoic-Palaeozoic. Abbreviation: J-PT, Jurassic-Permo-Triassic

Predominantly Archaean basement 


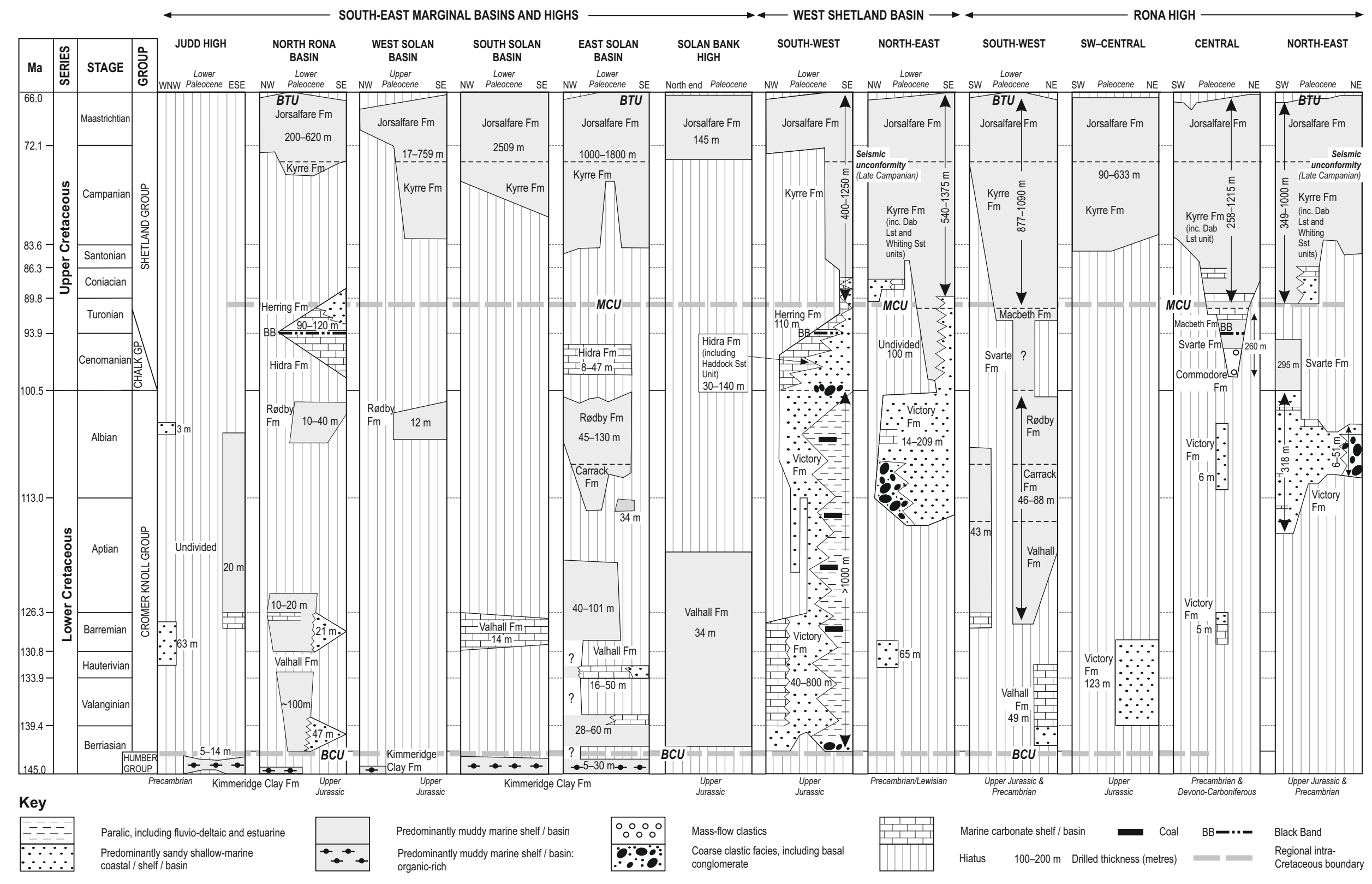


Fig. 5

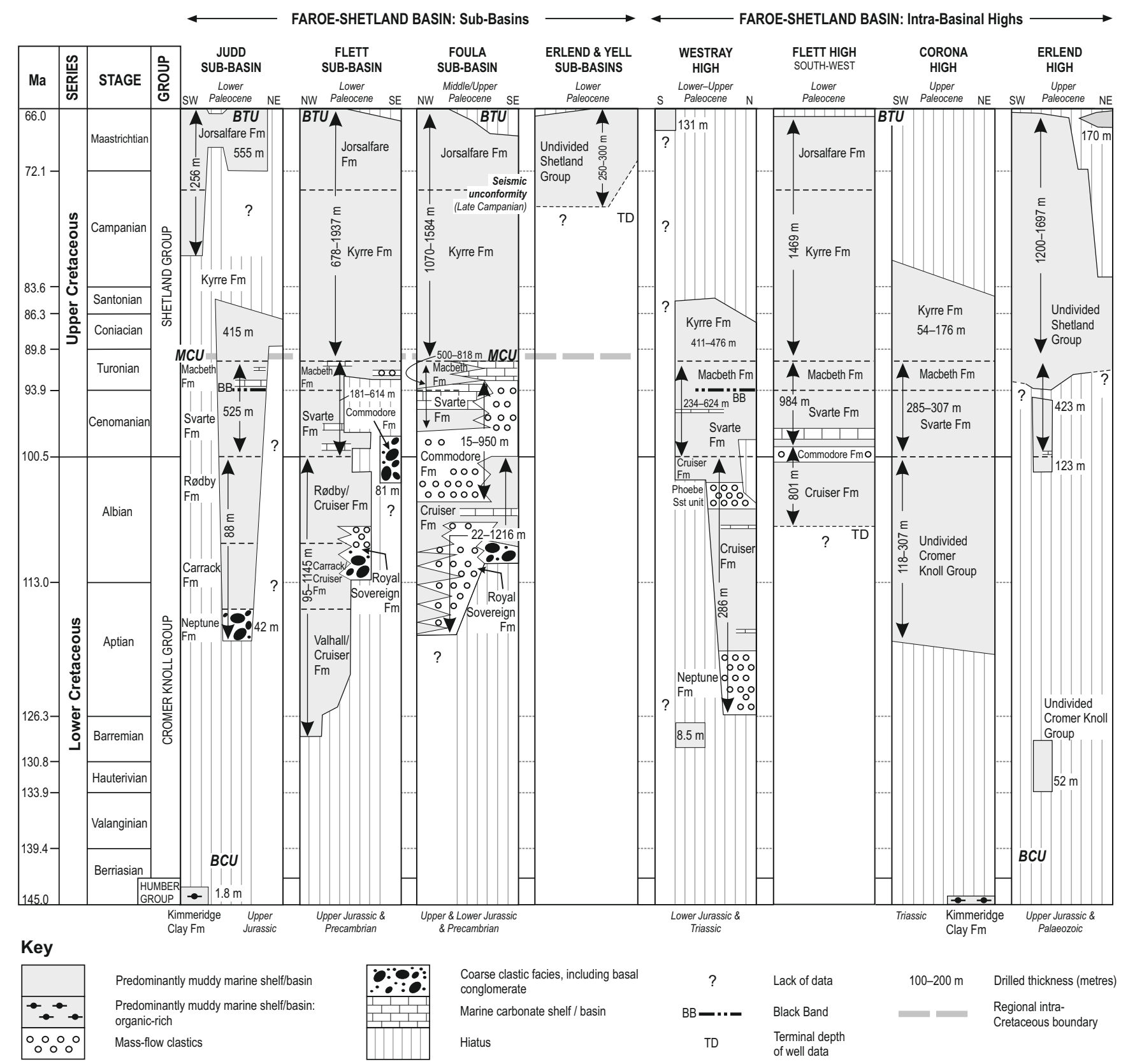


Fig. 6

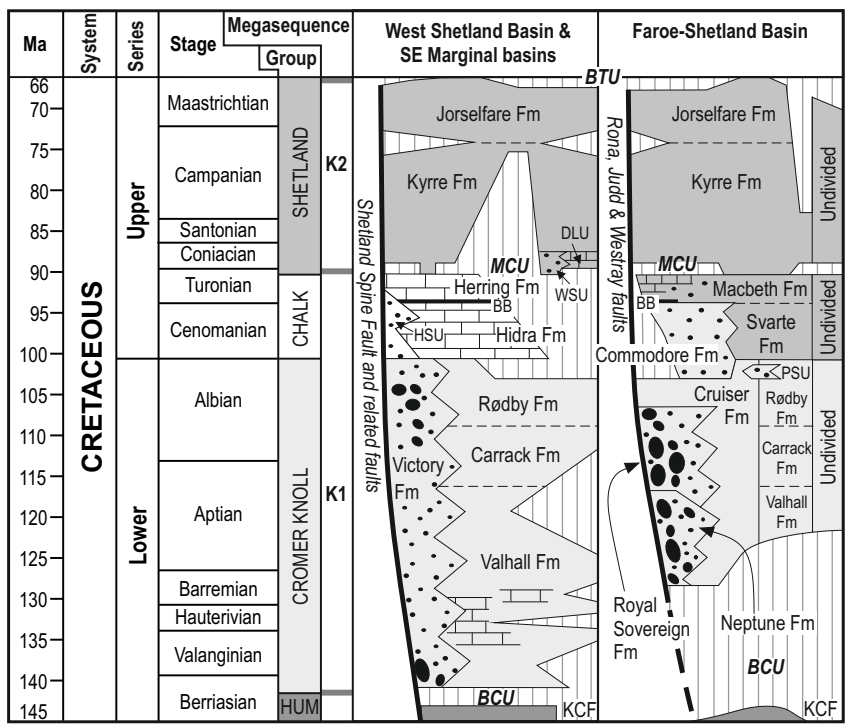

Key to lithological and other symbols

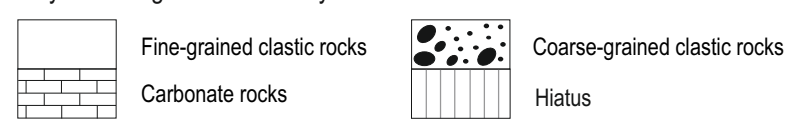


Fig. 7

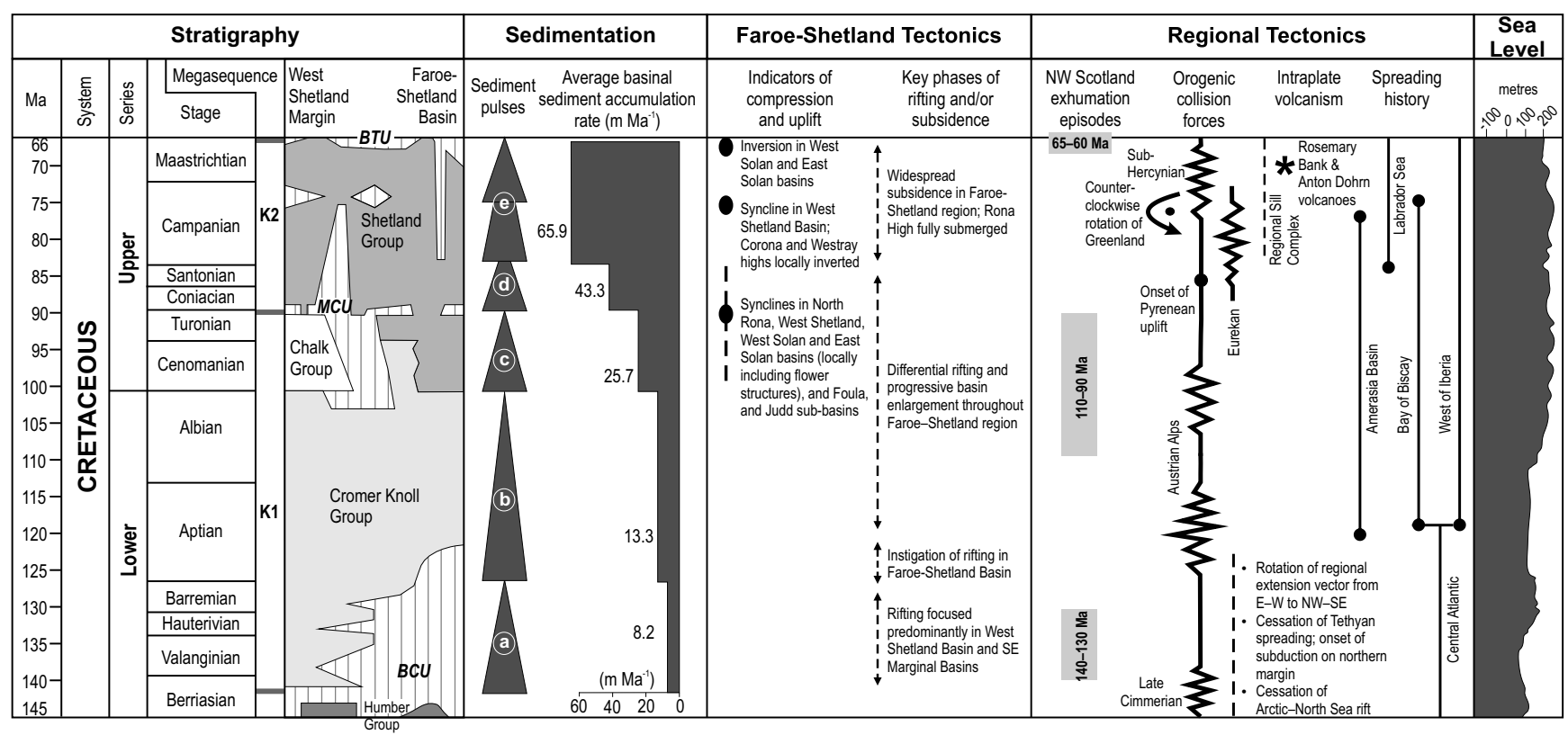


Fig. 8
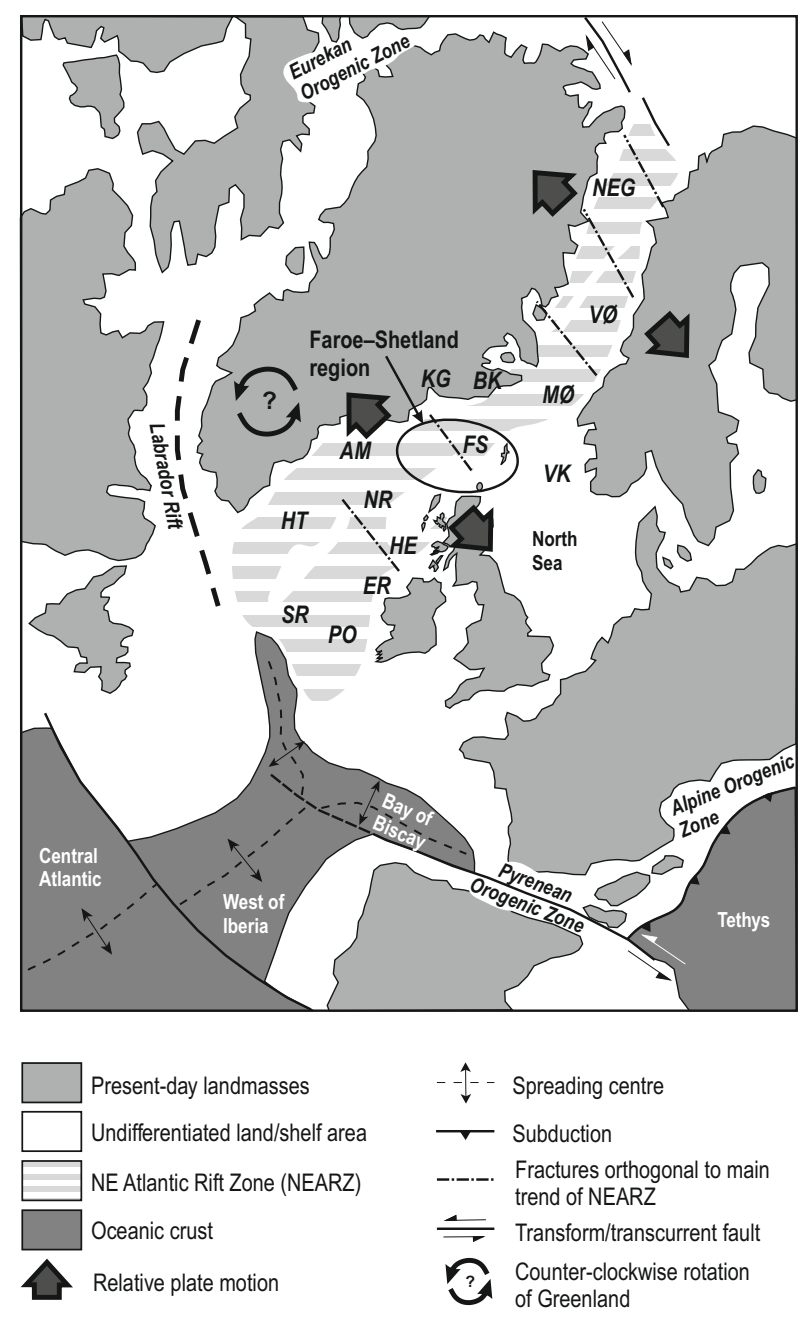
Fig. 9
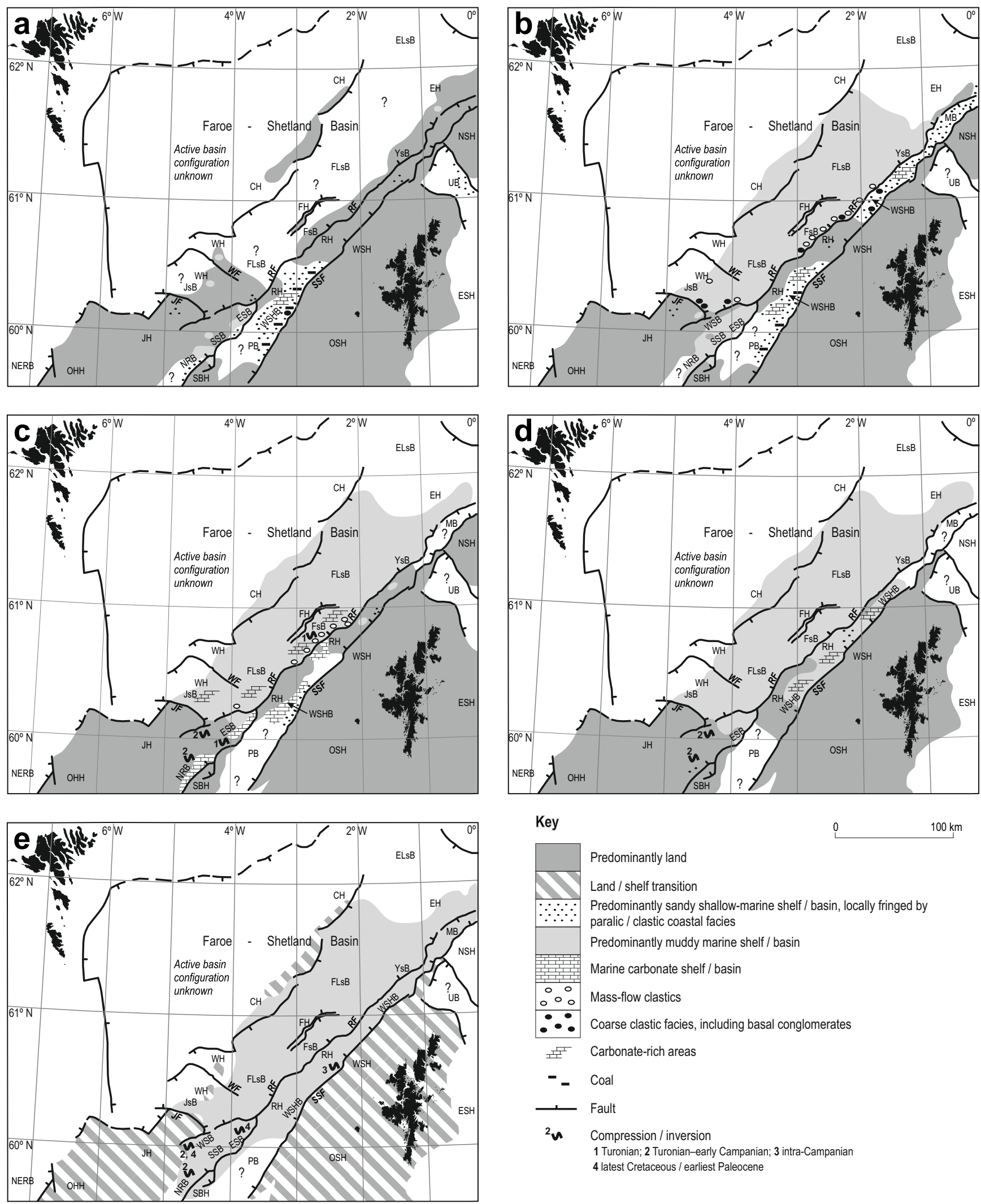

Key

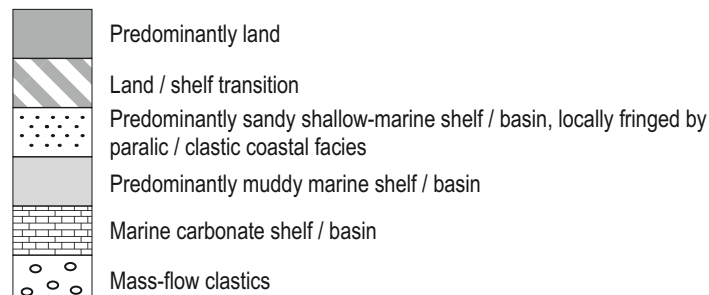

$\therefore$ Coarse clastic facies, including basal conglomerates

도 Carbonate-rich areas

- Coal

工_ Fault

$2^{2}$ Compression/ inversion

1 Turonian; 2 Turonian-early Campanian; 3 intra-Campanian 4 latest Cretaceous / earliest Paleocene 


\begin{tabular}{|c|c|}
\hline Structure & Well \\
\hline North Rona Basin & 202/2-1, 202/3-1A, 202/3-2, 202/8-1, 202/12-1 \\
\hline West Solan Basin & 202/3a-3, 204/29a-2 \\
\hline South Solan Basin & $202 / 4-1$ \\
\hline East Solan Basin & $\begin{array}{l}\text { 204/30a-2, 204/30a-3, 205/26a-2, 205/26a-3, } \\
\text { 205/26a-4, 205/26a-5z, 205/26a-6, 205/27-2 }\end{array}$ \\
\hline \multirow[t]{2}{*}{ West Shetland Basin } & $\begin{array}{l}\text { SW: 205/20-2, 205/23-1, 205/25-1, 205/30-1, } \\
\text { 206/13-1, 206/16-1 }\end{array}$ \\
\hline & $\begin{array}{l}\text { NE: 206/9-1, 206/10a-1, 207/1-2, 207/1a-5, } \\
\text { 207/2-1, 208/23-1, 208/24-1A }\end{array}$ \\
\hline Judd High & 204/26-1, 1A, 204/27-a1, 204/28-1, 204/28-2 \\
\hline Solan Bank High & 202/9-1 \\
\hline \multirow[t]{4}{*}{ Rona High } & $\underline{\text { SW: }}$ 204/25-1, 204/30-1, 205/21-1a, 205/26-1 \\
\hline & SW/Central: 205/20-1, 205/23-2 \\
\hline & $\begin{array}{l}\text { Central: 206/7-1, 206/8-2, 206/8-4, 206/8-6A, } \\
\text { 206/9-2, 206/12-1, 206/12-2, 206/13a-2 }\end{array}$ \\
\hline & $\begin{array}{l}\text { NE: 207/1-1, 207/1-3, 207/1a-4, 208/27-1, } \\
\text { 208/27-2 }\end{array}$ \\
\hline Judd sub-Basin & $\begin{array}{l}\text { 204/14-1, 204/19-5, 204/23-1, 204/24a-6, } \\
\text { 204/25a-2, 204/25a-3, 204/25-b4, 204/29-1 }\end{array}$ \\
\hline Foula sub-Basin & $\begin{array}{l}\text { 205/10-4, 205/10-5A, 206/1-1A, 206/3-1, } \\
206 / 4-1,206 / 5-1,206 / 5-2,206 / 11-1\end{array}$ \\
\hline Flett sub-Basin & $\begin{array}{l}\text { 204/20-3, 205/8-1, 205/9-1, 205/12-1, 205/14- } \\
\text { 1, 205/14-2, 205/16-1, 205/16-2, 205/17a-1, } \\
\text { 205/17b-2, 205/21-2, 205/21b-3, 205/22-1A, } \\
\text { 206/1-2, 206/1-3, 206/2-1A, 208/17-1, 208/17- } \\
\text { 2, 208/21-1, 208/22-1, 208/26-1, 214/27-1, } \\
\text { 214/28-1, 214/29-1, 214/30-1 }\end{array}$ \\
\hline Yell sub-Basin & $208 / 15-2$ \\
\hline Erlend sub-Basin & $219 / 27-1$ \\
\hline Westray High & $\begin{array}{l}\text { 204/15-2, 204/19-1, 204/19-2, 204/19-3A, } \\
\text { 204/19-9, 204/24-1A, 204/24a-2, 204/24a-3, } \\
\text { 204/24a-7, }\end{array}$ \\
\hline Flett High & 205/10-1A, 205/10-2, 205/10-3, 205/14-3, \\
\hline Corona High & 213/23-1, 214/9-1 \\
\hline Erlend High & $\begin{array}{l}\text { 209/3-1A, 209/4-1A, 209/6-1, 209/9-1A, } \\
\text { 209/12-1 }\end{array}$ \\
\hline
\end{tabular}




\begin{tabular}{|c|c|c|}
\hline Lithostratigraphy & Lithology & Depositional environment \\
\hline \multicolumn{3}{|l|}{ SHETLAND GROUP } \\
\hline Jorsalfare Formation & $\begin{array}{l}\text { Calcareous mudstone with sporadic interbedded argillaceous } \\
\text { limestone and rare sandstone. }\end{array}$ & $\begin{array}{l}\text { Aerobic marine siliciclastic shelf to basin (neritic-upper } \\
\text { bathyal zone). }\end{array}$ \\
\hline Kyrre Formation & $\begin{array}{l}\text { Non-calcareous mudstone with sporadic limestone, dolomite, } \\
\text { sandstone and siltstone. In West Shetland Basin, mudstone } \\
\text { grades to basal sandstone and limestone-rich facies, named the } \\
\text { Whiting Sandstone and Dab Limestone units. }\end{array}$ & $\begin{array}{l}\text { Partially restricted marine outer shelf to basin (neritic- } \\
\text { bathyal zone). Dab Limestone deposited on inner shelf; } \\
\text { Whiting Sandstone deposited as storm-generated shelf } \\
\text { sandstone. }\end{array}$ \\
\hline Macbeth Formation & $\begin{array}{l}\text { Variably calcareous mudstone with interbedded limestone, } \\
\text { minor dolomite and sporadic sandstone and siltstone. Base } \\
\text { locally marked by Black Band (see Herring Formation). }\end{array}$ & $\begin{array}{l}\text { Predominantly aerobic marine mixed siliciclastic-carbonate } \\
\text { shelf (neritic zone). Black Band indicates intermittent } \\
\text { anaerobic conditions. }\end{array}$ \\
\hline Svarte Formation & $\begin{array}{l}\text { Calcareous mudstone with interbedded limestone, argillaceous } \\
\text { limestone and sporadic siltstone. }\end{array}$ & Aerobic marine siliciclastic shelf (neritic zone). \\
\hline \multicolumn{3}{|l|}{ CHALK GROUP } \\
\hline Herring Formation & $\begin{array}{l}\text { Cryptocrystalline limestone with interbedded argillaceous } \\
\text { limestone and mudstone, and high gamma pyritic mudstone - } \\
\text { Black Band - at base. }\end{array}$ & $\begin{array}{l}\text { Mostly aerobic carbonate shelf (neritic zone), though } \\
\text { Black Band represents minor pulse of anaerobic } \\
\text { conditions. }\end{array}$ \\
\hline Hidra Formation & $\begin{array}{l}\text { Fine-grained limestone and argillaceous limestone with } \\
\text { interbedded mudstone, which, in West Shetland Basin, pass } \\
\text { laterally to the sandstone-rich Haddock Sandstone Unit. }\end{array}$ & $\begin{array}{l}\text { Aerobic carbonate shelf fringed by shallow-marine sands } \\
\text { derived from West Shetland Platform (neritic zone). }\end{array}$ \\
\hline \multicolumn{3}{|l|}{$\begin{array}{l}\text { CROMER KNOLL } \\
\text { GROUP }\end{array}$} \\
\hline Commodore Formation & $\begin{array}{l}\text { Fine- to medium-grained sandstone, locally pebbly (including } \\
\text { shell debris) and conglomeratic, with interbedded thin } \\
\text { mudstone and limestone. }\end{array}$ & $\begin{array}{l}\text { Mass-flow sandstones and proximal/basal conglomerates } \\
\text { on eastern margin of Faroe-Shetland Basin sourced from } \\
\text { Rona High. Correlative Phoebe Sandstone Unit sourced } \\
\text { from Judd or Westray highs }\end{array}$ \\
\hline Rødby Formation & $\begin{array}{l}\text { Calcareous mudstone interbedded with thin limestone, } \\
\text { siltstone and sandstone. }\end{array}$ & Predominantly aerobic marine shelf (neritic zone). \\
\hline Carrack Formation & $\begin{array}{l}\text { Non-calcareous, carbonaceous and pyritic mudstone and } \\
\text { siltstone. }\end{array}$ & Predominantly restricted anaerobic marine shelf/basin. \\
\hline Cruiser Formation & $\begin{array}{l}\text { Non-calcareous, carbonaceous and pyritic mudstone with } \\
\text { sporadic, paler-coloured and bioturbated thin siltstone, fine- } \\
\text { grained sandstone and limestone. }\end{array}$ & $\begin{array}{l}\text { Marine shelf/basin with fluctuating anaerobic-aerobic } \\
\text { bottom waters. }\end{array}$ \\
\hline $\begin{array}{l}\text { Royal Sovereign } \\
\text { Formation }\end{array}$ & $\begin{array}{l}\text { Conglomerate and fine- to coarse-grained and locally pebbly } \\
\text { sandstone with interbedded mudstone. }\end{array}$ & $\begin{array}{l}\text { Mass-flow deposits and proximal/basal conglomerates on } \\
\text { eastern margin of Faroe-Shetland Basin sourced from } \\
\text { Rona High. }\end{array}$ \\
\hline Neptune Formation & $\begin{array}{l}\text { Fine- to medium-grained sandstone and conglomerate with } \\
\text { interbedded thin mudstone. }\end{array}$ & $\begin{array}{l}\text { Mass-flow sandstones and proximal/basal conglomerates } \\
\text { in SW Faroe-Shetland basin possibly sourced from the } \\
\text { Westray or Judd highs. }\end{array}$ \\
\hline Valhall Formation & $\begin{array}{l}\text { Calcareous mudstone grading into thin argillaceous limestone, } \\
\text { and sporadic sandstone. }\end{array}$ & Predominantly aerobic marine shelf/basin. \\
\hline Victory Formation & $\begin{array}{l}\text { Fine- to medium-grained sandstone, locally conglomeratic at } \\
\text { base, with sporadic mudstone and thin coal. }\end{array}$ & $\begin{array}{l}\text { Paralic (including fan deltas) to shallow marine shelf } \\
\text { (littoral-neritic zone) in the West Shetland Basin. Coal } \\
\text { beds indicate episodic exposure of the delta plain. }\end{array}$ \\
\hline
\end{tabular}




\begin{tabular}{|c|c|c|}
\hline Basin & Regional setting & Gross stratigraphy of basin-fill in $\mathrm{K} 1$ and $\mathrm{K} 2$ megasequences \\
\hline $\begin{array}{l}\text { North } \\
\text { Rona } \\
\text { Basin }^{1}\end{array}$ & $\begin{array}{l}\text { NNE-trending half- } \\
\text { graben bounded by } \\
\text { Solan Bank High. }\end{array}$ & $\begin{array}{l}\text { K1 megasequence comprises a synclinally-disposed punctuated sequence of Valanginian-Turonian rocks, } \\
\text { which onlap Upper Jurassic-lowest Cretaceous (Humber Group) strata; the K2 megasequence is a wedge- } \\
\text { shaped unit that preserves Campanian-Maastrichtian rocks, which thicken towards the Solan Bank High and } \\
\text { onlap the K1 megasequence. }\end{array}$ \\
\hline $\begin{array}{l}\text { West Solan } \\
\text { Basin }^{1,2,3}\end{array}$ & $\begin{array}{l}\text { NNE-trending basin } \\
\text { situated at SW end of } \\
\text { the Rona High. }\end{array}$ & $\begin{array}{l}\text { Both megasequences thin and/or terminate on the Judd High }{ }^{2} \text {. The K1 megasequence is composed of Albian } \\
\text { (and older?) rocks, which onlap Upper Jurassic-lowest Cretaceous (Humber Group) strata, and which are in } \\
\text { turn onlapped by Campanian-Maastrichtian rocks of the K2 megasequence. The basin-fill was inverted in the } \\
\text { latest Cretaceous-earliest Paleocene }{ }^{3} \text {. }\end{array}$ \\
\hline $\begin{array}{l}\text { East/South } \\
\text { Solan } \\
\text { basins } \\
1,3,4\end{array}$ & $\begin{array}{l}\text { NNE-trending half- } \\
\text { grabens; bounded in } \\
\text { SE by Solan Bank } \\
\text { High. }\end{array}$ & $\begin{array}{l}\text { The K1 megasequence consists of a punctuated Valanginian-Cenomanian sequence, which onlaps Upper } \\
\text { Jurassic-lowest Cretaceous (Humber Group) strata, and which has been faulted and folded in the East Solan } \\
\text { Basin }{ }^{3} \text { prior to the deposition and onlap of the Coniacian-Maastrichtian rocks of the K2 megasequence. In the } \\
\text { East Solan Basin, the K2 megasequence thickens eastward towards the main bounding fault. }\end{array}$ \\
\hline $\begin{array}{l}\text { West } \\
\text { Shetland } \\
\text { Basin }^{1,4,5,6,7}\end{array}$ & $\begin{array}{l}\text { NNE-trending half } \\
\text { graben bounded by } \\
\text { Shetland Spine Fault } \\
\text { and Rona High. } \\
\text { Discrete NE and SW } \\
\text { depocentres. }\end{array}$ & $\begin{array}{l}\text { Both the K1 and K2 megasequences are wedge-shaped, thicken towards the Shetland Spine Fault, and thin onto } \\
\text { the Rona High. The K1 megasequence ranges from late Berriasian to Turonian in age in the SW, but is largely } \\
\text { of Aptian-Turonian age in the NE. These rocks rest unconformable on Upper Jurassic and older strata. The K1 } \\
\text { megasequence is absent from footwall crest due to late Albian-late Coniacian uplift. The K2 megasequence } \\
\text { comprises Coniacian-Maastrichtian rocks that onlap K1, and is itself locally cut by a late Campanian } \\
\text { unconformity }{ }^{6} \text {, which is linked to a phase of folding or sagging; the resulting syncline is infilled and onlapped } \\
\text { by uppermost Campanian-Maastrichtian rocks. }\end{array}$ \\
\hline $\begin{array}{l}\text { Judd sub- } \\
\text { Basin }^{1,2,4}\end{array}$ & $\begin{array}{l}\text { Generally NE-trending } \\
\text { basin bounded by the } \\
\text { Judd, Rona, Westray } \\
\text { and Sjùrður highs. }\end{array}$ & $\begin{array}{l}\text { The K1 megasequence thickens into the footwalls of the main basin-bounding faults and thins over } \\
\text { hangingwall crests, and has an Aptian-Turonian age range; these rocks unconformably overlie Upper Jurassic- } \\
\text { lowest Cretaceous (Humber Group) strata. The K2 megasequence is wedge-shaped, locally downlaps onto K1, } \\
\text { and ranges from Coniacian to Maastrichtian in age. The observed seismic stratigraphy becomes obscured in the } \\
\text { NW part of the sub-basin where high-amplitude reflections associated with sills are prevalent. }\end{array}$ \\
\hline $\begin{array}{l}\text { Flett sub- } \\
\text { Basin }\end{array}$ & $\begin{array}{l}\text { NE-trending basin } \\
\text { bounded centrally by } \\
\text { Corona, Rona and } \\
\text { Flett highs. }\end{array}$ & $\begin{array}{l}\text { Generally poor seismic resolution throughout the Flett sub-Basin, with stratigraphic continuity commonly } \\
\text { disrupted by sporadic high-amplitude sills. Nevertheless, there are seismic-stratigraphic indications of a gross } \\
\text { bipartite sub-division of the succession, especially adjacent to the Rona, Flett and Corona highs, where a } \\
\text { Barremian-Cenomanian/Turonian age range for the lower seismic unit (K1) is compatible to adjacent basins } \\
\text { and sub-basins. Coniacian to Maastrichtian rocks form the upper unit (K2). }\end{array}$ \\
\hline $\begin{array}{l}\text { Foula sub- } \\
\text { Basin }^{1,4,5,7}\end{array}$ & $\begin{array}{l}\text { NE-trending half } \\
\text { graben bounded by } \\
\text { Rona and Flett highs. }\end{array}$ & $\begin{array}{l}\text { The K1 megasequence is a synclinally-disposed unit of Aptian-Turonian age, which is thickest adjacent to the } \\
\text { Flett High, displays progressive onlap onto the Rona High, and overlies Jurassic and Precambrian rocks. The } \\
\text { K2 megasequence comprises a more uniformly-thick unit of Coniacian-Maastrichtian deposits that onlap K1. } \\
\text { Later (Paleocene?) faulting has locally modified its geometry. }\end{array}$ \\
\hline $\begin{array}{l}\text { Erlend sub- } \\
\text { Basin }^{1}\end{array}$ & $\begin{array}{l}\text { Mesozoic basin poorly } \\
\text { defined. SE margin } \\
\text { marked by Erlend and } \\
\text { North Shetland highs. }\end{array}$ & $\begin{array}{l}\text { Seismic profiles across SE margin of basin indicate two main seismic units that might be separated by a low- } \\
\text { angle unconformity, with the upper unit onlapping onto the lower unit. Much of the basin fill is obscured by } \\
\text { discontinuous high-amplitude reflections that represent sills. Oldest rocks penetrated are of Campanian age. }\end{array}$ \\
\hline $\begin{array}{l}\text { Yell sub- } \\
\text { Basin }^{8}\end{array}$ & $\begin{array}{l}\text { NE-trending half- } \\
\text { graben at NE-end of } \\
\text { Rona High }\end{array}$ & $\begin{array}{l}\text { A gross stratigraphic basin-fill comparable to the West Shetland Basin has been suggested for this sub-basin }{ }^{8} \text {. } \\
\text { Oldest rocks penetrated are of Maastrichtian age. }\end{array}$ \\
\hline
\end{tabular}




\begin{tabular}{lrrrrr}
\hline \multicolumn{3}{l}{ Maximum-drilled sediment thickness (metres) } & & & \\
\hline & LB-B & A-A & C-T & C-S & C-M \\
North Rona Basin & 110 & 40 & 120 & 60 & 620 \\
West Solan Basin & 0 & 12 & 0 & 0 & 759 \\
South Solan Basin & 14 & 0 & 0 & 0 & 2509 \\
East Solan Basin & 150 & 183 & 47 & 0 & 1800 \\
SW West Shetland Basin & 800 & 200 & 250 & 247 & 1000 \\
NE West Shetland Basin & 65 & 200 & 100 & 290 & 1085 \\
Judd sub-Basin & 0 & 88 & 525 & 415 & 555 \\
Flett sub-Basin & 23 & 1145 & 614 & 794 & 1143 \\
Foula sub-Basin & 0 & 1216 & 818 & 609 & 975 \\
& & & & & \\
Sediment accumulation rate (m Ma & & & & & \\
& LB-B & A-A & C-T & C-S & C-M \\
North Rona Basin & 7.0 & 1.6 & 11.2 & 9.7 & 35.2 \\
West Solan Basin & 0 & 0.5 & 0 & 0 & 43 \\
South Solan Basin & 0.9 & 0 & 0 & 0 & 142.5 \\
East Solan Basin & 9.5 & 7.1 & 4.4 & 0 & 102.5 \\
SW West Shetland Basin & 51.0 & 7.6 & 23.4 & 39.8 & 56.8 \\
NE West Shetland Basin & 4.1 & 7.8 & 9.4 & 46.8 & 61.7 \\
Judd sub-Basin & 0 & 3.4 & 49.0 & 67.0 & 31.5 \\
Flett sub-Basin & 1.5 & 44.4 & 57.4 & 128.0 & 65.0 \\
Foula sub-Basin & 0 & 47.1 & 76.4 & 98.2 & 55.4 \\
Average & $\mathbf{8 . 2}$ & $\mathbf{1 3 . 3}$ & $\mathbf{2 5 . 7}$ & $\mathbf{4 3 . 3}$ & $\mathbf{6 5 . 9}$ \\
\hline
\end{tabular}




\begin{tabular}{|c|c|}
\hline Stage/boundary & Summary of basin development \\
\hline Early Berriasian & Widespread uplift and erosion \\
\hline \multicolumn{2}{|c|}{ BCU - Base Cretaceous Unconformity } \\
\hline $\begin{array}{l}\text { Late Berriasian- } \\
\text { Barremian }\end{array}$ & $\begin{array}{l}\text { Rifting focused in SW West Shetland Basin; } \\
\text { more sporadic in SE Marginal Basins with } \\
\text { intermittent uplift and erosion }\end{array}$ \\
\hline Aptian-Albian & $\begin{array}{l}\text { Instigation of rifting in Faroe-Shetland Basin } \\
\text { (FSB), including submergence of } \\
\text { intrabasinal highs; SE Marginal Basins and } \\
\text { SW West Shetland Basin remain active; } \\
\text { rifting in NE West Shetland and Muckle } \\
\text { basins }\end{array}$ \\
\hline $\begin{array}{l}\text { Albian/Cenomanian } \\
\text { boundary }\end{array}$ & $\begin{array}{l}\text { Uplift and exposure of SE Marginal Basins, } \\
\text { NE West Shetland Basin, and intrabasinal } \\
\text { (FSB) northern Westray High }\end{array}$ \\
\hline Cenomanian-Turonian & $\begin{array}{l}\text { Rifting focused in FSB and SE West } \\
\text { Shetland Basin; sporadic in SE Marginal } \\
\text { Basins; contractional deformation in FSB } \\
\text { and SE Marginal Basins }\end{array}$ \\
\hline \multicolumn{2}{|c|}{ MCU - 'Mid' Cretaceous Unconformity } \\
\hline Coniacian-Santonian & $\begin{array}{l}\text { Rifting focused in FSB (peak sediment } \\
\text { accumulation rates) and SW/NE West } \\
\text { Shetland Basin; SE Marginal Basins largely } \\
\text { exposed and possibly still subject to } \\
\text { contractional deformation; Rona High } \\
\text { partially submerged }\end{array}$ \\
\hline $\begin{array}{l}\text { Campanian- } \\
\text { Maastrichtian }\end{array}$ & $\begin{array}{l}\text { Widespread submergence in all basins; } \\
\text { highest sediment accumulation rates in SE } \\
\text { Marginal Basins and SW/NE West Shetland } \\
\text { basin; Rona High totally submerged; } \\
\text { intrabasinal (FSB) Corona and Westray } \\
\text { highs re-exposed; contractional deformation } \\
\text { in West Shetland Basin }\end{array}$ \\
\hline \multicolumn{2}{|c|}{ BTU - Base Tertiary Unconformity } \\
\hline $\begin{array}{l}\text { Maastrichtian/Paleocene } \\
\text { boundary }\end{array}$ & $\begin{array}{l}\text { Widespread uplift and erosion of SE } \\
\text { Marginal Basins, SW/NE West Shetland } \\
\text { Basin and intrabasinal (FSB) Corona and } \\
\text { Westray highs; contractional deformation in } \\
\text { SE Marginal Basins }\end{array}$ \\
\hline
\end{tabular}

